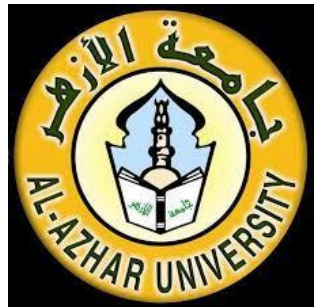

كليسـة اللغة العربية بأسيوط

المبلة العلميسة

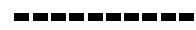

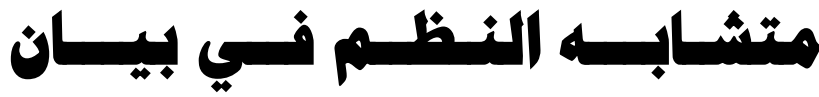 \\ مقيقة الدنيـا وعدم الاغتـرار بهـا
}

$$
\begin{aligned}
& \text { פ) } \\
& \text { د/ شمسة بنست سعـود الهــرانسي } \\
& \text { أستاذ اللغة العربية المساعد }
\end{aligned}
$$

كلية التربية بالحرج جامعة الأمير سطام بن عبدالعزيز

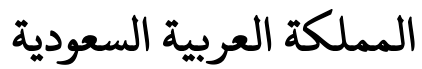

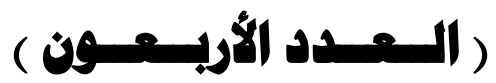

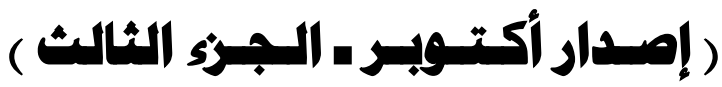

$(p r+r) / D I \varepsilon \varepsilon r)$ 


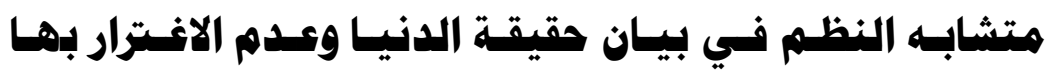

حصـة بنت سعود الهززانسي

قسم اللغة العربية، كلية التربية بالخرج، جامعة الأمير سطام بن عبدالعزيز، المملكة العربية السعودية.

\section{البريـد الإلكتــرونسي:}

|llill

يهدف هذا البحث إلى تبيان مواضـع الآيـات المتثـابهة في التحذير من الدنيا، وتدبر دلالات تلك الآيـات في سياقها، وجاء هذا البحث في مقدمة وتمهيد ومبحثين يعقبهما خاتمة، على النحو الآتي: المبحث الأول: متشابه النظم في الآيات الدالة على ملى أن الدنيا متاع. المبحث الثاني: متثـابه النظم في الآيات الدالة على أن الدنيا لعب البـ ولههو. خاتمـة، وتثـمل على أبرز النتائج والتوصيات. وقد اتبعت في هذه الدراسـة المنهج الوصفي القائم على الاستقراء وتصنيف الآيات المتثـابهات في التحذير من الانيا والموازنة بين هذه الآيات من خلال السياق. وخرجت الدراسة ببعض التتائج من أهمها: ارتباط تركيب الآيات المتثابهة في التحذير من الانيا وعدم الاغترار بها ارتباطًا وثيقًا بالسياق الأي وردت فيه، ووفرة استخدام أسلوب القصر في هذه الآيـات؛ وذلك لما يتميز به أسلوب القصر؛ لاشتماله على النفي والإثبات، وذلك متوافق مـع طبيعة الحديث عن الدينا، وييـان حقيقتها. وأدعو في خاتمـة البحث المختصين بالدراسـات القرآنية إلى الالتفات إلى موضوع متثابه النظم؛ لأهميته، خاصـة فيمـا يتعلق بالجانب التطبيقي منه، فهي الثمرة الحقيقة لورود الأساليب البلاغية المتعددة التي تتنوع وتتعدد التهاد باختلاف المقامات والغايات، وسيظل القرآن معجزًا، ولن نحيط بوجوه إعجازه. الكلمهات الإنتساحيـة: متثابـه النظم، بيان، حقيقة الدنيا، عدم الاغترار. 


\section{Title: Similar expressions of explaining the reality of the world and not being deceived by it.}

Hessa bint Saud Al Hazani

Department of Arabic Language, College of Education in Al-Kharj, Prince Sattam bin Abdulaziz University, Kingdom of Saudi Arabia.

Email: h.alhazzani@psau.edu.sa

\section{Abstract:}

This research aims to explain the positions of similar verses which include warnings about the world, and carful analysis of the implications of those verses in their contexts. This research includes an introduction, a preface, and two topics, followed by a conclusion: The first topic: The similar expressions of the verses implying that the world is pleasure. The second topic: The similar expressions of the verses implying that the world is play and amusement. Conclusion, which includes the most important results and recommendations. In this research, I followed the descriptive approach based on induction and classification of verses that are similar in warnings about the world and the comparison of these verses through their context. The research came out with some results, the most important of which are: the link between the structure of similar verses in warnings against the world closely with the context in which they were mentioned, and the abundance of the use of the narrowing of meaning method in these verses, due to what narrowing of meaning method is characterized by; it includes negation and affirmation, and this is consistent with the nature of the discussion about the world, and the reality of its truth. In the conclusion of the research, I call attention to the specialists of Quranic studies to focus on the theme of similar expressions; Because of its importance, especially with regard to the practical aspect of it, it is the real fruit of the flowers of the multiple rhetorical methods that vary according to different situations and goals, and the Qur'an will remain a miracle, and we will not be able to cover all the aspects of its miraculousness.

Keywords: Similar Expressions - Reality - The reality of the world Not being deceived. 


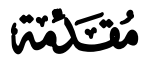

الحمد لله رب العالمين، والصلاة والسلام على أشرف الأنبياء والمرسلين، وعلى

$$
\text { آله وصحبه أجمعين، ويعد:- }
$$

فإن من أعظم النعم التي أنعم الله بها علينا أن شرع لنا أفضل شرائع دينه، ويعث فينا أفضل رسله، وأنزل علينا أفضل كتبه، وإن من أجلّ البحوث قرًّا ومكانة ما كانت في خدمة كثابه العزيز، التي تسعى إلى إبراز بلاغة القرآن الكريم، ومـا تميز به نظمه وأسلويه حتى بلغ حد الإعجاز.

وإن مسن جوانسب إعجـاز القـرآن الكريم: المتثـابه اللفظي في نظم القـرآن الكريم، وما ينطوي عليه من فروقات واختلافات دقيقة، تتجلى من خلال السباق الأي وردت فيه الآيات المتشابهة، حيث وضعت كل لفظة في سياقها اللائق بها، فلا تأتي لفظة مكان أخرى.

وقد كان من أسباب اختياري لهذا الموضوع مـا ينطوي عليه الموضوع من أهمية الوقوف على الآيـات المتشـابهات وعلاقتها بالسياق الذي ترد فيـه وإبراز جانب من جوانب إعجاز القرآن الكريم في موضوع مرتبط بالحياة، وهو الآيـات المتثـابهة في التحذير من الدنيا، كما أن رغبتي الملحة في البحث في القرآن الكريم وتدبر هذا الجانب الإعجازي كانت دافعًا لي للبحث في هذا الموضوع. والغاية من هذه الدراسة: هي تبيان مواضـع الآيات المتشـابهة في التحذير من الانيا، وتدبر دلالات تلك الآيات في سياقها، والكشف عن أسرار استعمالها، وييان الإعجاز القرآني بذكر المسائل البلاغية المتصلة بها. وقد اتبعت في هذه الدراسـة المنهج الوصفي القائم على الاستقراء لآيات الاراسة، وتحليلها تحليلا بلاغيَّا، ببيان وجوه الاتفاق، ووجوه الاختلاف بين آيات الاراسة، من خلال اتباع الآتي: 
/ /تصنيف الآيات المتثنابهات في التحذير من الانيا حسب مباحث البحث، وتناول هذه الآيات بالثرح والتحليل، وبيان ما فيها من فنون بلاغية. r / الموازنة بين هذه الآيات المتشابهات واستعمالاتها من خلال السياق. وتوجد في الساحة العلمية دراستان هما الأقرب لهذا الموضسوع، أمـا الأولى فهـي أطروحـة دكتـوراه بعنـوان ( المتشــابه اللفظـي في القـرآن الكـريم وأسـراره البلاغيـة) للباحث الدكتور، صـالح بن عبدالله الشثري، وقد جاعت أطروحته في ثثلاثة أبواب يسبقها مقدمة وتمهيد، ويعقبها خاتمة، فيها أبرز النتائج التي توصل إليها، تحدث في الباب الأول عن تراث أهل العلم في توجيه المتثـابه اللفظي، وفيه خمسة فصول استعرض فيها الكتب التي قامت عليها رسالته، معرفًا بالمؤلف وموضحًا مصادر كل كتاب وقضاياه، وفي الباب الثاني تناول الكلمـة في المتثـابه اللفظي، وجاء في خمسة فصول أيضًا: ( الاختلاف بين الآيات المتثـابهة في اختيار الصيغة، وفي الإفراد والجمع، والتذكير والتأنيث، والتعريف والتنكير، وفي الحروف، أما الباب الثالث فقد تتاول فيه التراكيب في المتثـابه اللفظي، وقد جاء هذا الباب في ثثلاثة فصول: ( الاختلاف في الآيات المتثـابهة في الذكر والحذف وفي التقديم والتأخير وفي الفصل والوصل)، ومما سبق يتضـح أن دراسـة الباحث جاءت في عدد من الآيات المتشابهة ذات موضوعات مختلفة. أما الدراسـة الثانية فهي كتاب بعنوان: (من بلاغة المتشابه اللفظي في القرآن الكريم) للاكتور محمد بن علي الصامل، وكان أصل الكتاب برنامجًا في إذاعة القرآن الكريم في المملكة العربية السعودية، ثم أعاد هذا البرنامج على هيئة بحث علمي اكتفى فيه بالحديث عن عشرة مواضع مرتبة وفق ترتيب السور، ويالرجوع لهذه المواضع وجدتها كلها في سورة البقرة ومـا يشبهها في السور الأخرى، وتوجد دراسـة أخرى للاكتور فاضـل السـامرائي، بعنـوان: ( دراسـة المتشـابه اللفظي مـن آي التنزيـل في كتـاب مـلاك التأويـل )، وهذه الاراسـة خاصـة بدراسـة كتـاب مـلاك التأويـل لابـن الزبيـر الغرناطي، كما يوجد كتاب حول هذا الموضوع إلا أنه يعنى بالوقوف على الآيات 
المتشابهة وتبيان مواضعها دون ذكر الأسرار البلاغية في تلك الآيات، وهو كتاب: دليل الآيات متشـابهة الألفاظ في كتاب الله العزيز للدكتور سراج صـالح ملائكة، أما هذه الدراسة فإنها تختلف عن الدراسـات السـابقة في كونها تتـاول موضوعًا محددًا، وهو: التحذير من الدنيا من جهة متثـابه النظم في آيـات التحذير من الانيا، والتوقوف على تلك الآيات بالبحث واللدراسة.

وجاء هذا البحث في مقدمة وتمهيد ومبحثين يعقبها خاتمة، على التحو الآتي: المقدمة، وفيها أسباب اختيار الموضوع وأهميته والمنهج المتبع في هذا البحث والدراسات السابقة لهذا الموضوع. التمـهيد: ويتناول: أولاً: متشابه النظم: تعريفه وأهميته. ثانيًا: أهمية السياق في انتقاء الألفاظ وتحقيث الغرض. ثالثًا: المؤلفات في متشابه النظم رابعًا: آيات متثابه النظم في بيان حقيقة الدنيا. المبحث الأول: متثابه النظم في الآيات الدالة على أن الدنيا متاع. المبحث الثاني: متثابه النظم في الآيات الدالة على أن الانيا لعب ولهو. خاتمة، وتثمل على أبرز النتائج والتوصيات. ثبت المصادر والمراجع.

وأرجو من الله أن يكون هذا البحث قد حقق الهدف منـه في الكثف عن الأسرار البلاغية في المتشابه اللفظي في آيات التحذير من الدنيا، وأسأل الله أن يكون علمًا نافعًا وأن يتجاوز عن الخطأ والنسيان وزلات الأقلام. 


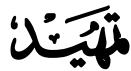

جاء القرآن الكريم معجزًا للعرب، وتحداهم بأن يأتوا بمثل أقصر سورة منهه،

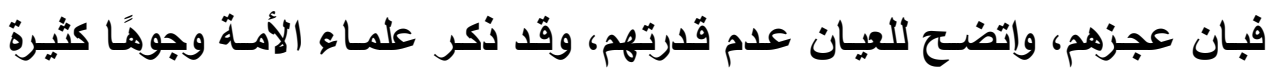

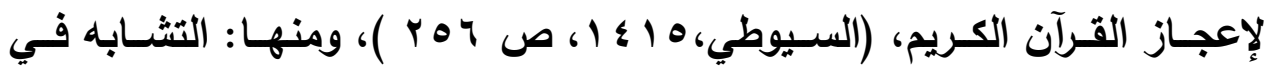
ألفاظه ومعانيه إلى حد يصل التطابق أحيانًا أو الاختلاف أحيانًا بالذكر والحذف أو أو

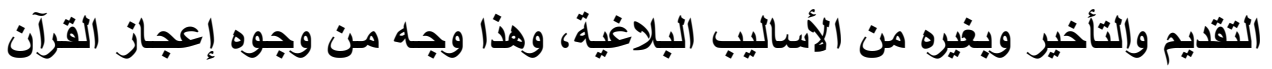

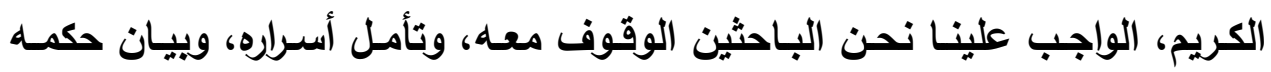

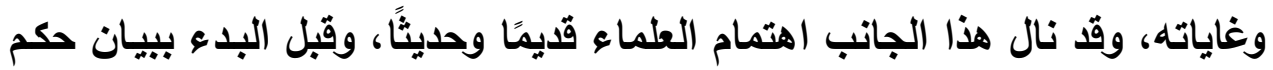
متثابه نظم هذه الآيات هذا الموضوع، يجدر بي الحديث عن معنى التشابه، وأثثر السياق في تحديد دلالات المتشابهات، بعد حصر آيات الاراسة وذكرها.

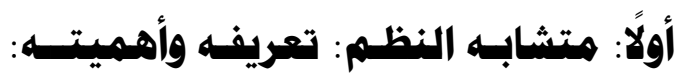
ورد المنسى اللغوي للمتثـابه في المعاجم العريبة، قال أحمد بن فارس:"

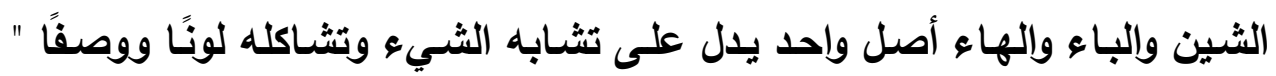

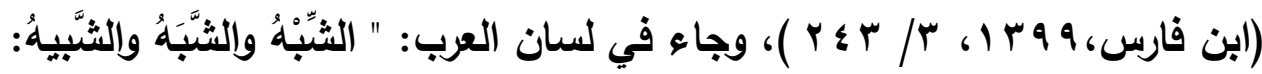

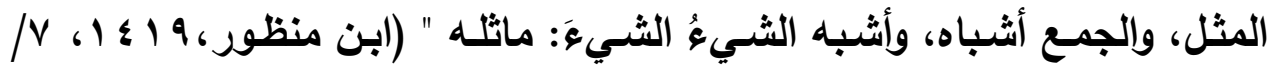

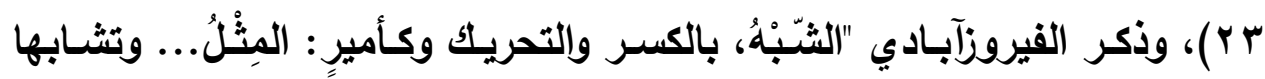

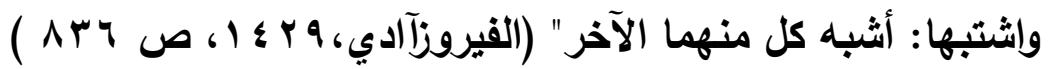
ومن هذه المعاني اللغوية يتبين المعنى الاصطلاحي، فقد عرفه الزركشي بقوله: "هو إيراد القصة الواحدة في صور شتى وفواصل مختلفة، ويكثر في إيراد

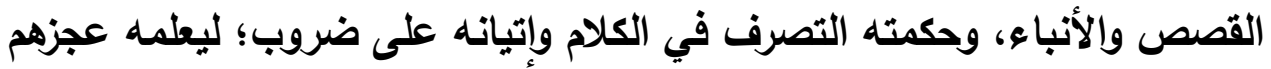

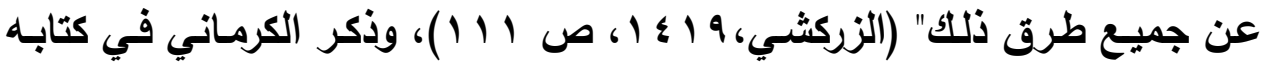
البرهان في توجيه متثابه القرآن: " فإن هذا الكتاب أذكر فيه الآيات المتثـابهات

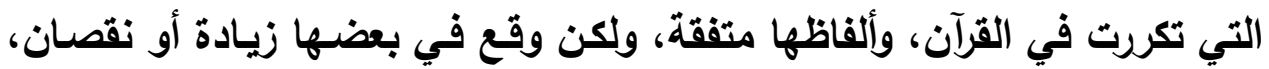


أو تقديم أو تأخير أو إبدال حرف مكان حرف أو غير ذلك مما يوجب اختلافًا بين

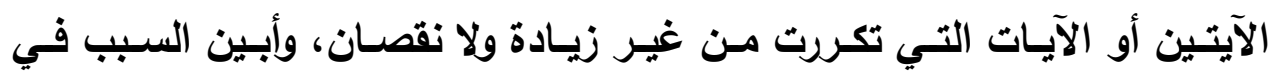

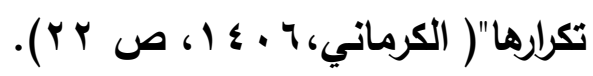

فالمقصود بالمتشـابه هنا: المتشابه اللفظي الذي يعني المماثلـة في النظم

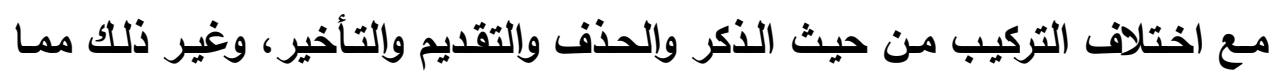
يظهر جانبًا من جوانب إعجاز القرآن الكريم ويلاغته.

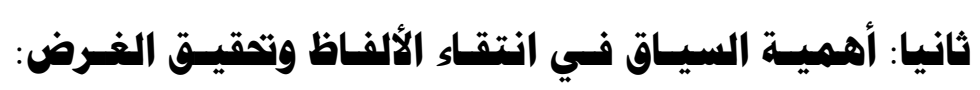
يعد السياق عنصرًا مههًَا في تحديد دلالة المفردة؛ ذلك أن معظم مفردات

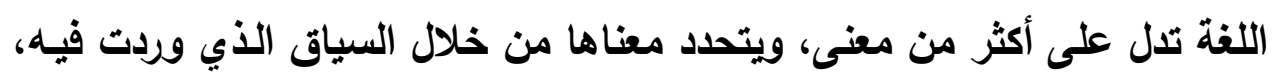

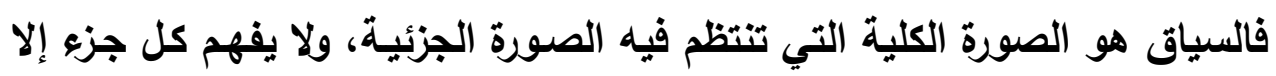

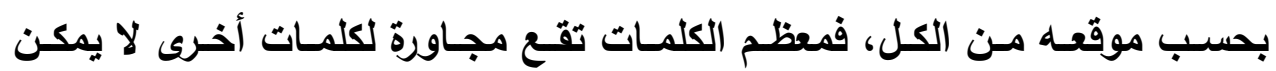

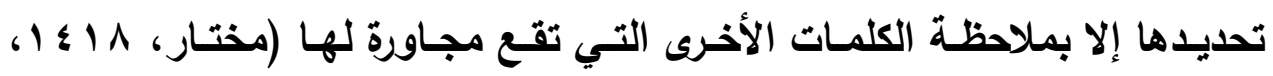
ص \& 7)، فالكلمة ترتبط من خلال السياق الذي ترد فيه بوثـائج قويـة بما قبلها

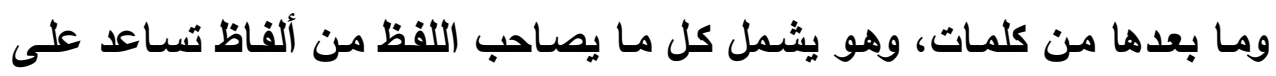

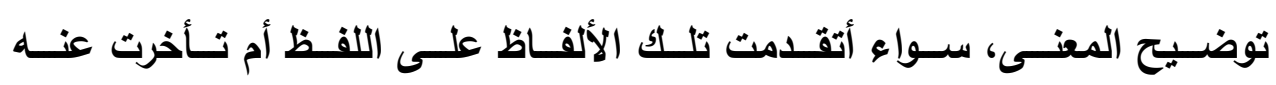

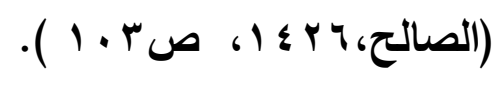

وقد اهتم علماء الأمة بالسياق اهتمامًا كبيرًا، وأولوه عناية فائقة من أجل

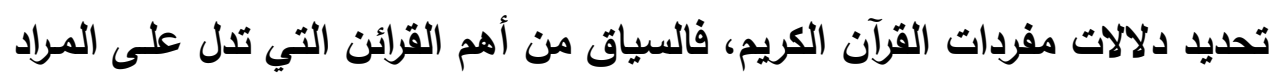

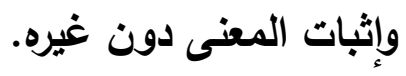

ومسن المفسرين الذين اعتنوا بالسياق الزمخشري في تفسيره ( الكشـاف)

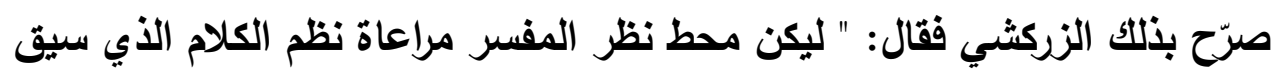

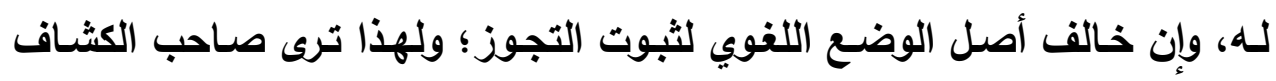

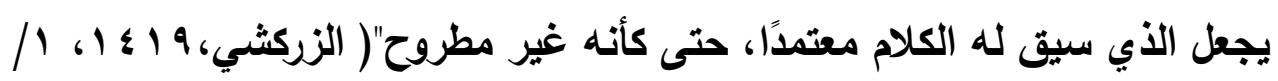




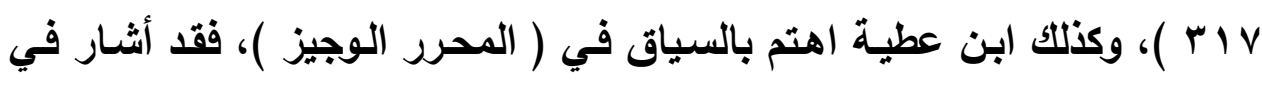

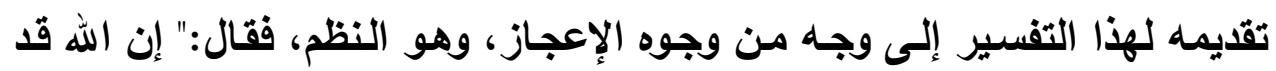

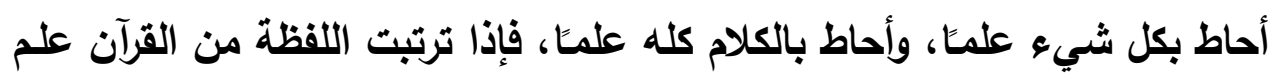

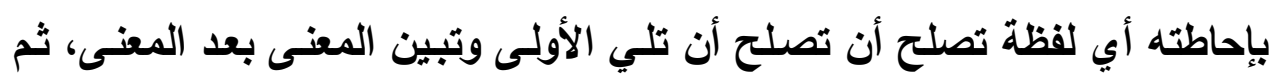

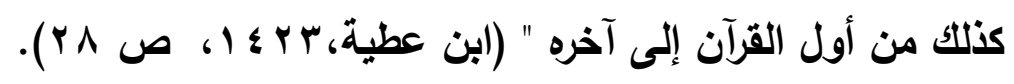

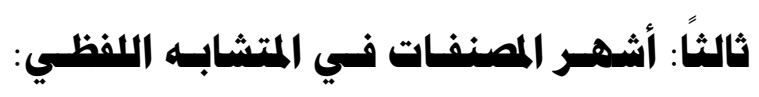

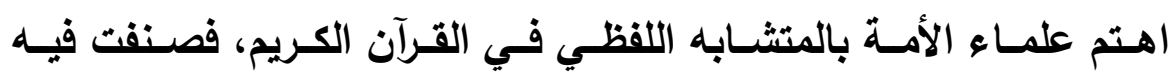

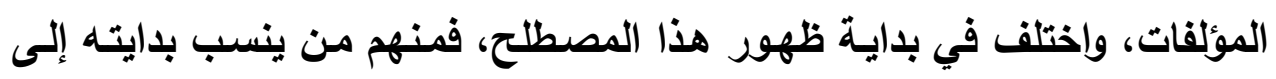

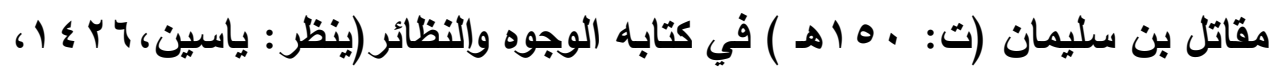

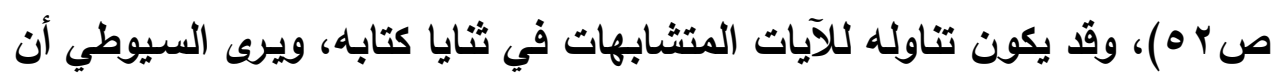

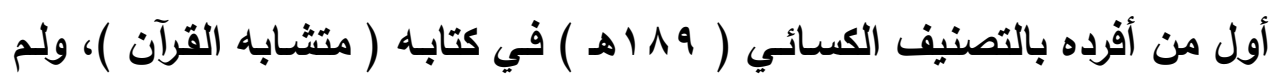

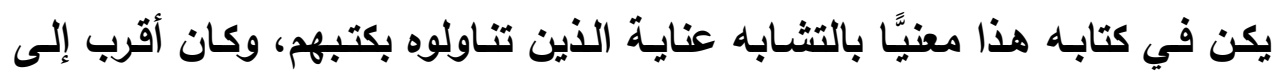

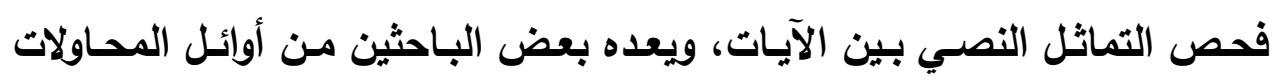

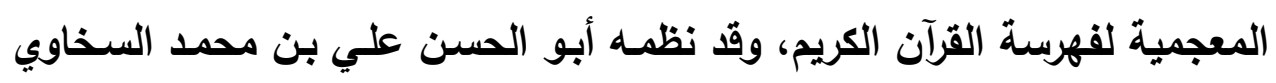

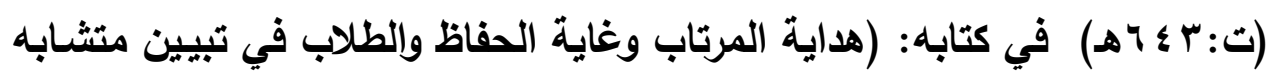

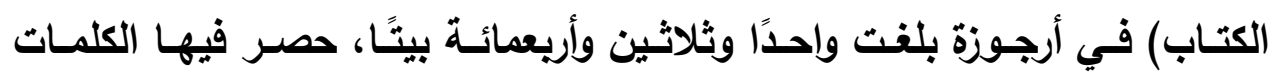

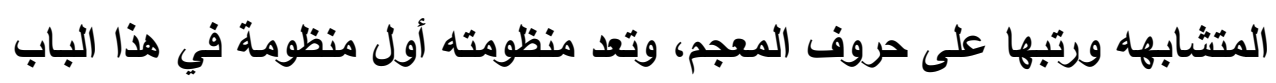

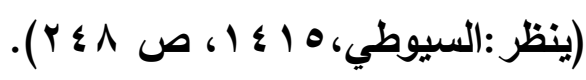
ومن المصنفات في المتثابه اللفظي، كتاب: (درة التنزيل وغرة التأويل في بيان الآيـات المتثـابهات في كتاب الله العزيز) لأبي عبدالله محمد بـن عبدابله الله

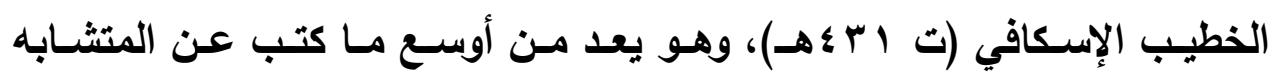

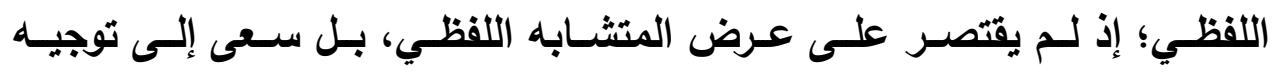

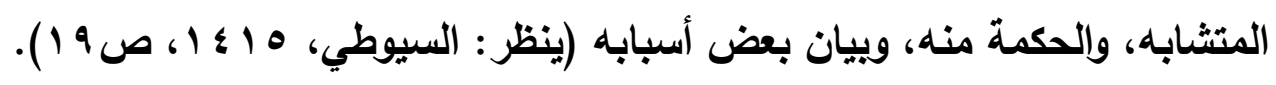


وكذلك مـن المصنفات في المتشـابه كتـاب ( مـلاك التأويـل القـاطع بـذوي الإلحاد والتعطيل في توجيه المتثابه اللفظ من آي التنزيل) لأبي جعفر أحمد بن إبراهيم ابن الزبيز الغرناطي، وقد تبلور هذا العلم عنده، واستقر، فأثثته في عنوانه

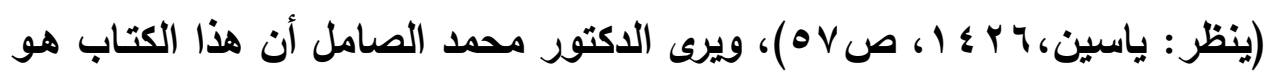

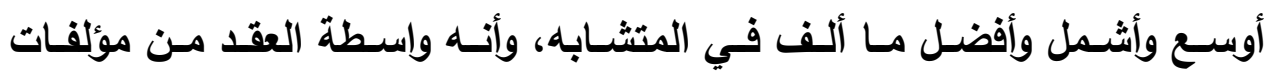
المتثابه اللفظي (ينظر: الصامل، Y Y \& ا، ص ع Y). ومن المؤلفات في العصر الحديث كتاب( من بلاغة المتثـابه اللفظي في القـرآن الكـريم ) للـدكتور محمــ بـن علـي الصـامل، تــاول فيـه بعـض الآيـات المتثـابهة في عثـرة مواضـع مرتبـة حسب ترتيب المصـف، وكتـاب ( دراسـة المتثابه اللفظي من آي التنزيل في كتاب ملاك التأويل )، وقف فيه المؤلف على هلى دراسة كتاب ملاك التأويل للغرناطي، ومن المؤلفات الحديثة أيضًا كتاب ( المبنى والمعنى في الآيـات المتشـابهات في القرآن الكريم ) للدكتور عبدالمجيد ياسين المجيد، تناول فيه بعض الآيات المتثابهات في وجه واحد من وجوه التشابه، من حيث التشابه في الحروف أو في الأسماء أو في الأفعال أو في التقديم والتأخير. إضافة إلى بعض المؤلفات في الإعجاز البلاغي التي تناولته ضمن الفصول

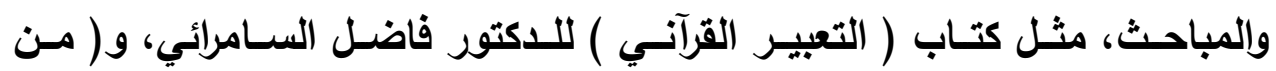
الإعجاز اللغوي في القرآن ) للاكتور مصطفى شعبان، والدكتور عبده الراجحي، وغيرها من المؤلفات.

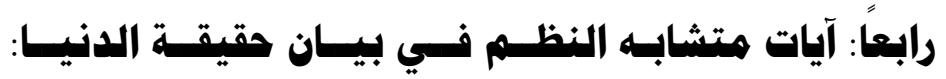
وفيمـا يأتي بيـان لآيـات الاراسـة، وحصر لها، رأيت من الأنسب ذكرهـا في

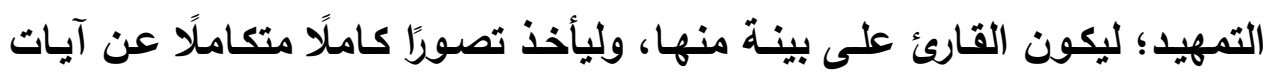

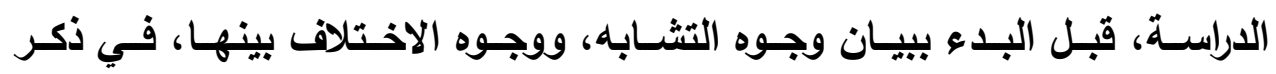
مضمونها، ويبان معانيها. 


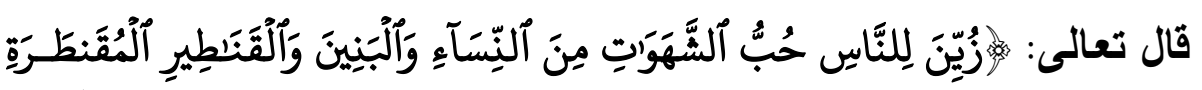

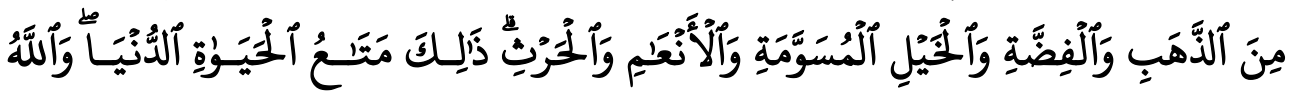

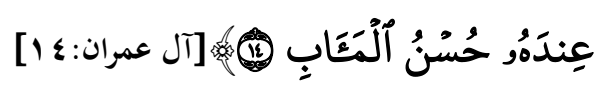

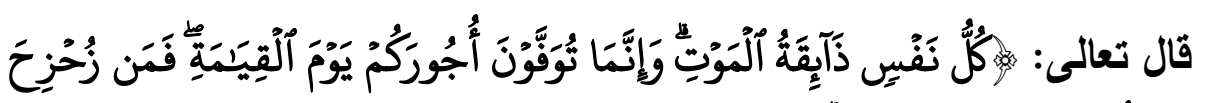

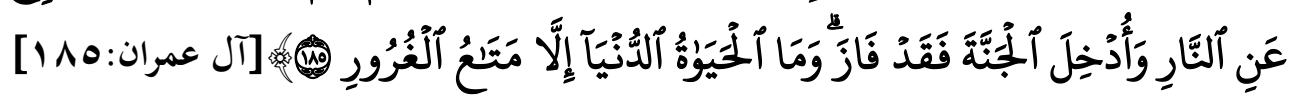

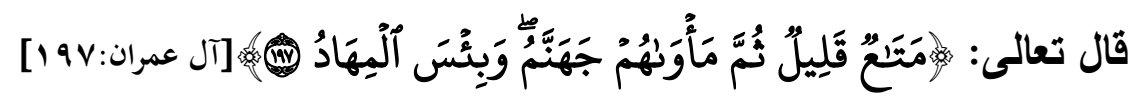

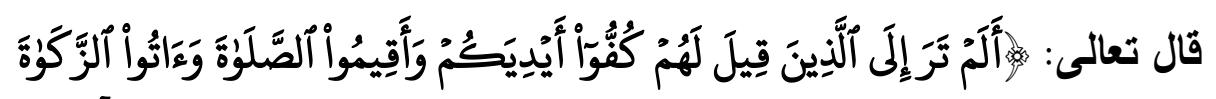

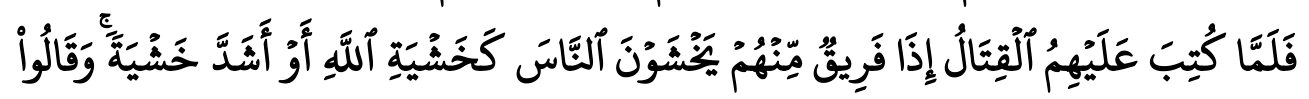

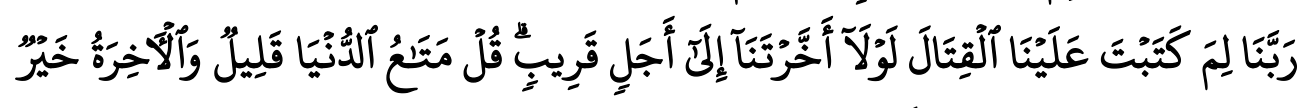

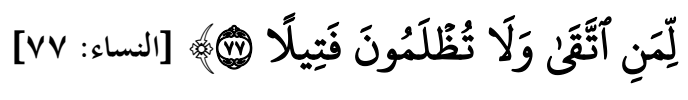

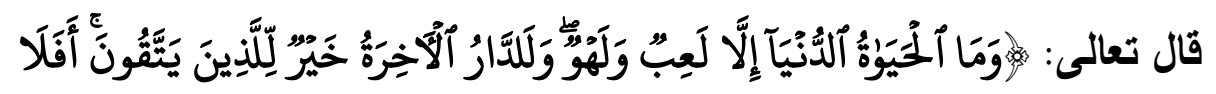

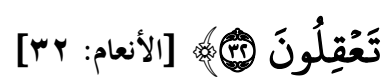

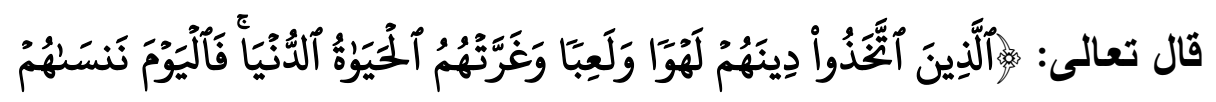

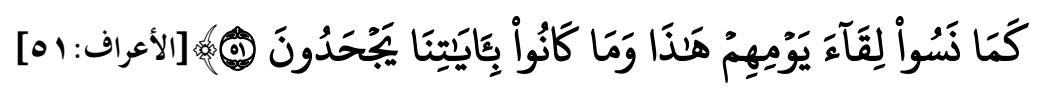

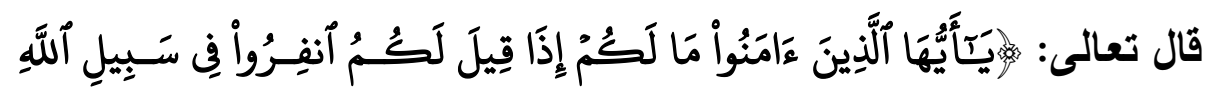

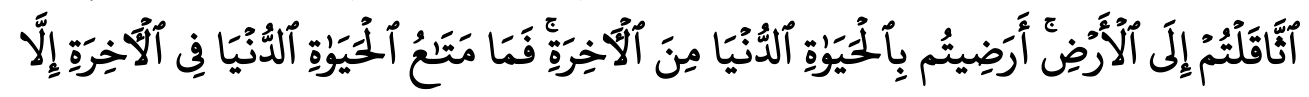

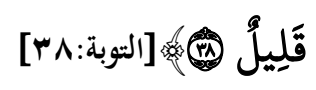

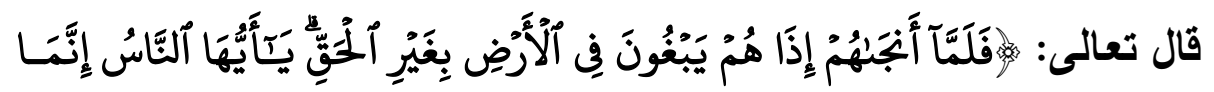

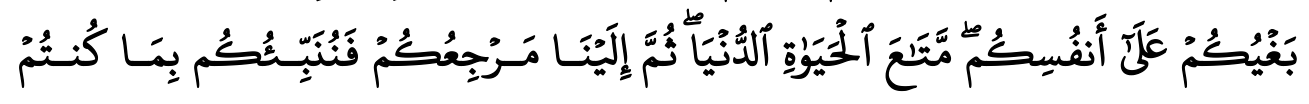
تَعْمَلُونَ 


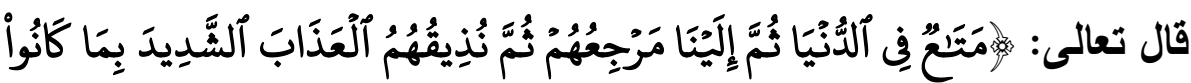

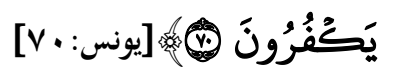

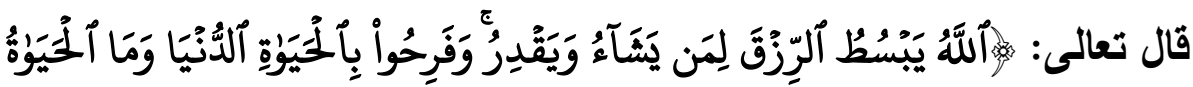

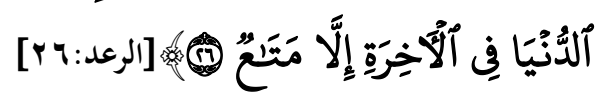

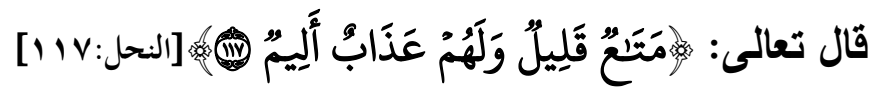

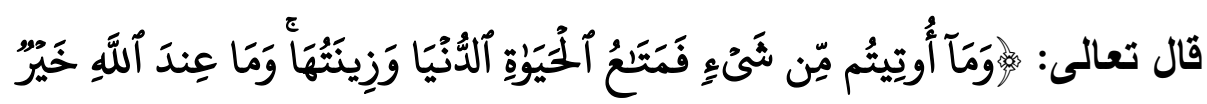

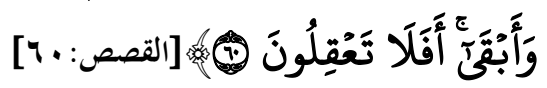

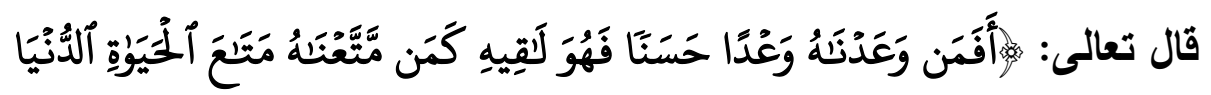

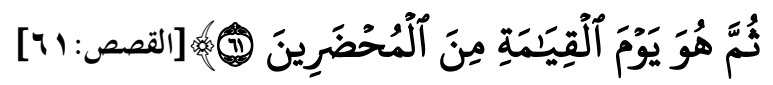

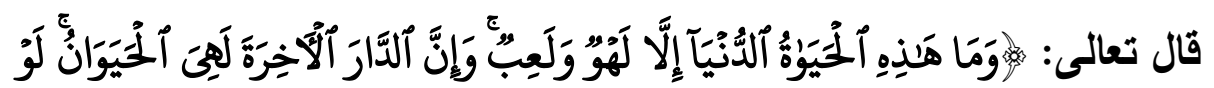

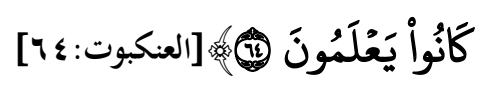

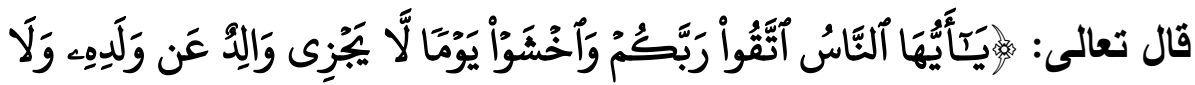

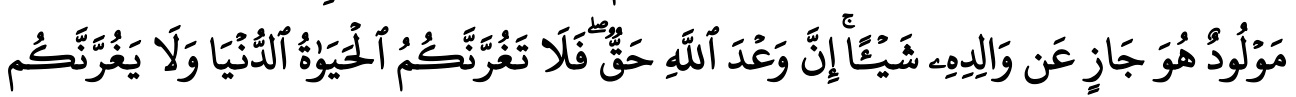

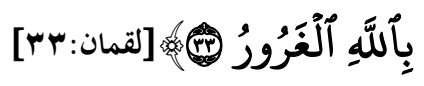

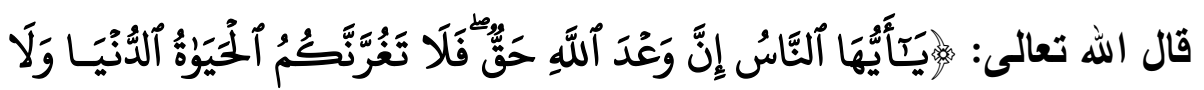

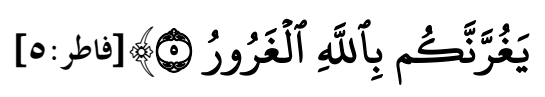

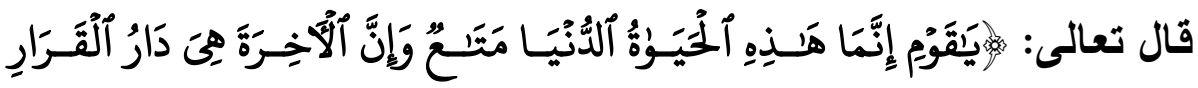

$$
\text { [ra: }
$$

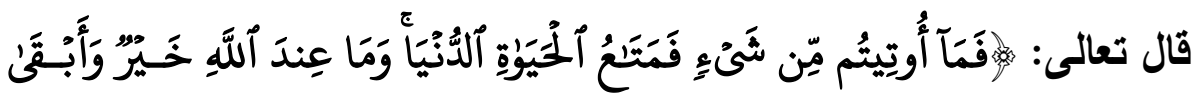

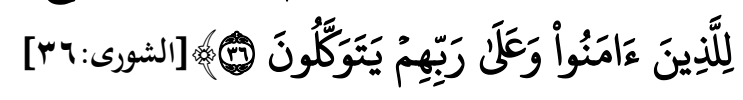




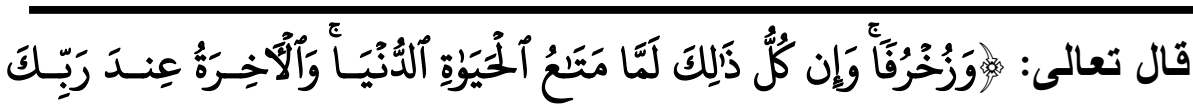

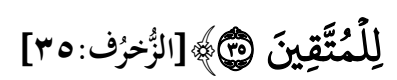

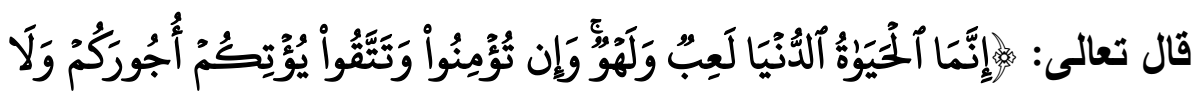

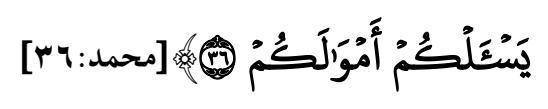

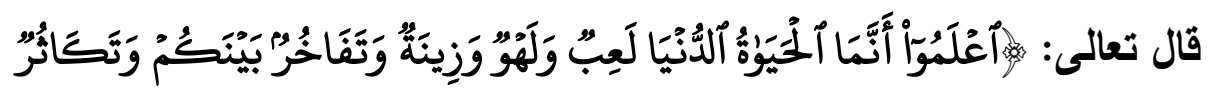

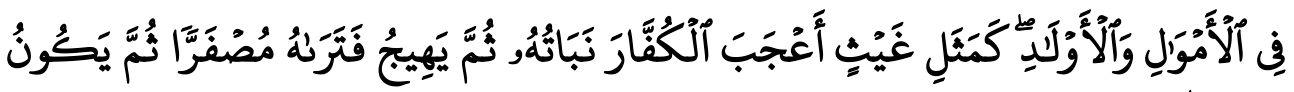

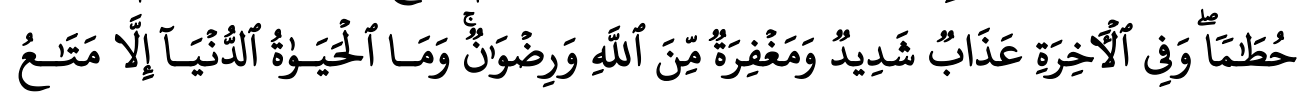

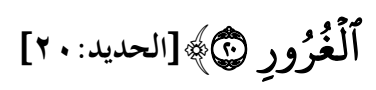

****************** 


\section{البمشث الأول \\ متشابه النظم في الآيات الدالة}

على أن الدنيا متاع

ورد في عدة مواضـع مسن القـرآن الكـريم أن الـدنيا متـاع، وذلـك في سـياق

التحذير منها وعدم الاغترار بها، والمتـاع "مـا يتمتع بـه وينقضسي " (ابن عاشور،

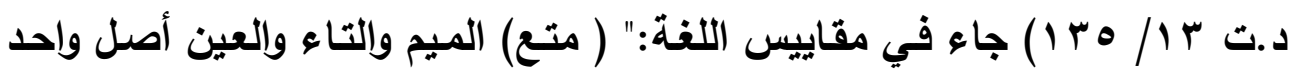
يال على منفعة وامتداد مدة في خير، منـه: استمتعتُ بالشيء، والمتعة وإلمتاع:

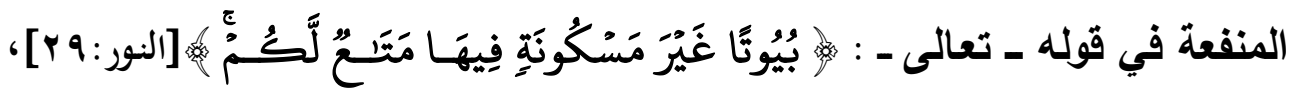
ومتعت المطلقة بالشيء؛ لأنها تنتفع به، ويقال: أمتعتُ بمالي، بمعنى تمتعتُ به".

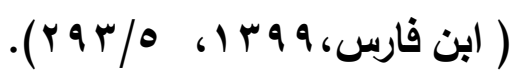

والأصل في ( متـع ) إمـا أن يكون: التلذذ العاجل، أو يكون الأصل فيه: الامتداد والارتفاع

وجاء في بصائر ذوي التمييز: " متع النهار يمتع - كمنع يمنع - متوعًا: ارتفع، والماتع: الطويل من كل شيء، وحبل مـاتع: جيد الفتل، ونبيذ مـاتع: شديا الحمرة، وكل شيع جيد فهو ماتع، والمتاع: السلعة، والمتاع: المنفعة، وما تمتعت

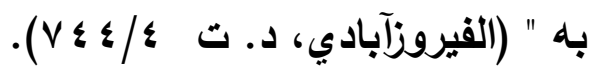
ويتضح مما سبق أن المتاع هو: لذة ومنفعة مع امتداد زمن. وقد ورد لفظ المتاع في القرآن الكريم بمختلف الصيخ في سبعين موضعًا، يختلف معنـاه بـاختلاف السياق الذي ورد فيه، حيث جاء هذا اللفظ في القرآن الكريم على عدة وجوه ذكرها الدامغاني بقولـه: " تقسير المتـاع على أربعة أوجـه: البلاغ - المنافع - متعة الطلاق - المعدن" (الدامغاني، \& \& 1، ص ب ب ع)، وقد جاء هذا اللفظ في سبياق التحذير من الدنيا في خمسـة عشر موضسعًا، وجاءت الآيات المتثابهة منها كالآتي: 


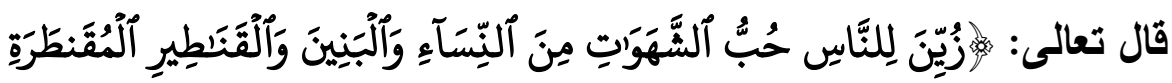

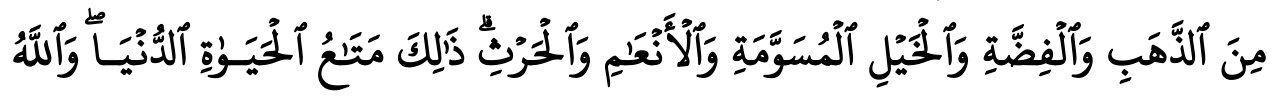

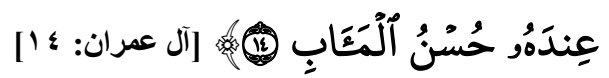

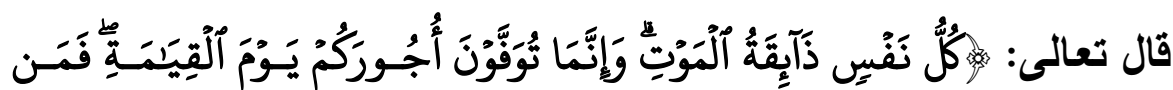

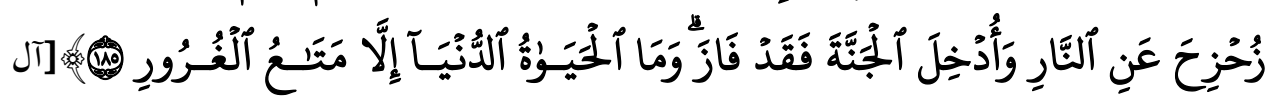
[مران:110

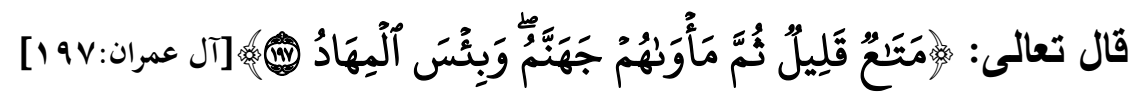

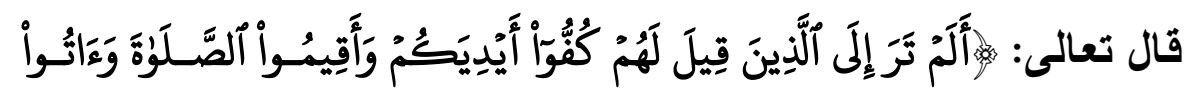

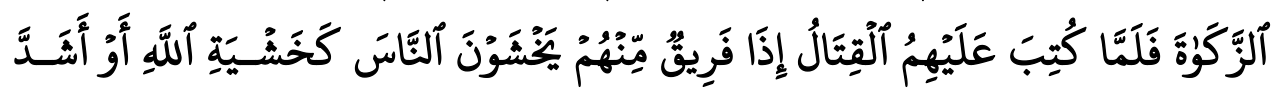

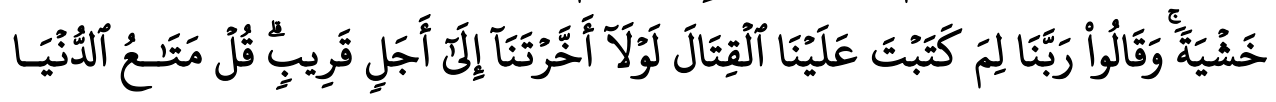

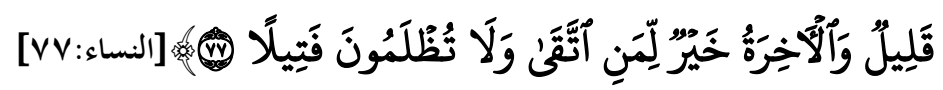

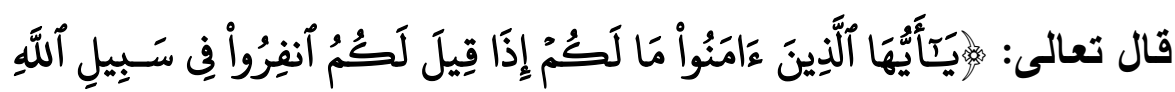

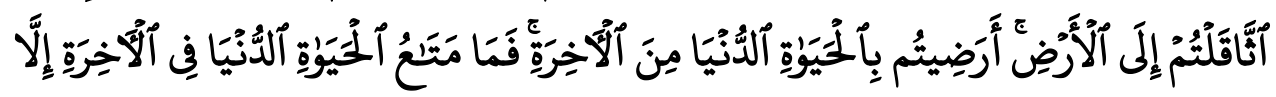

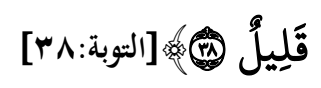

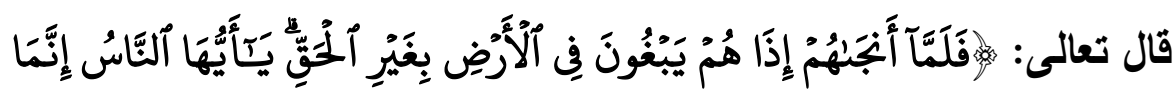

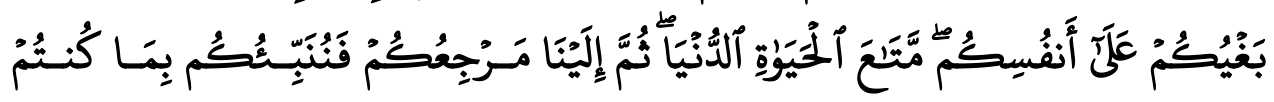
تَعْمَلُونَ

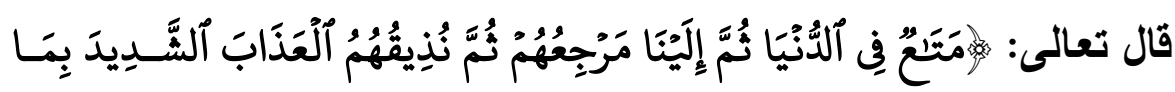

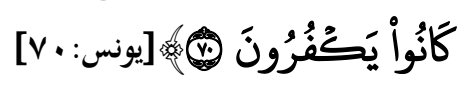

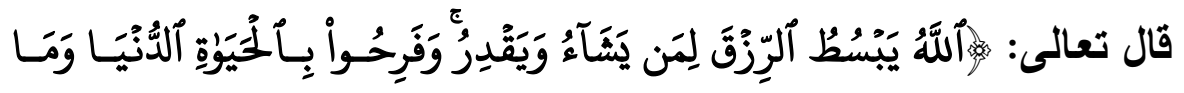

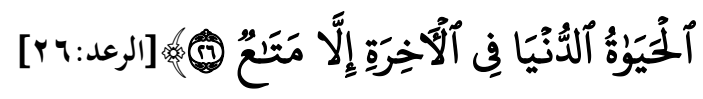




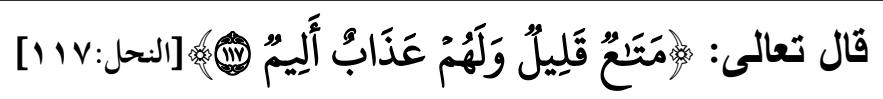

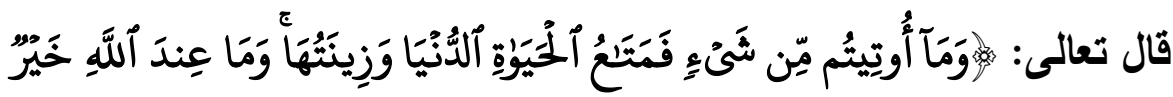

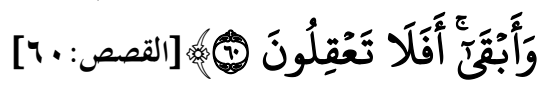

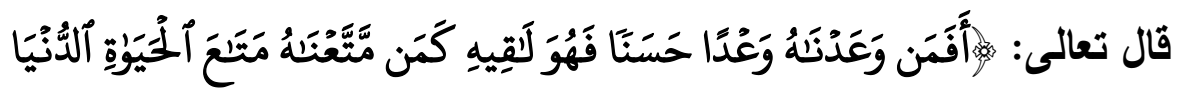

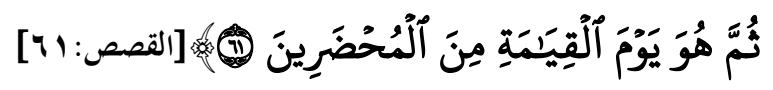

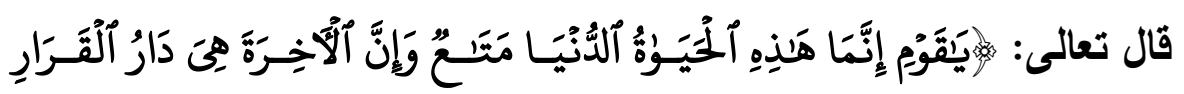
[ra: غ غ

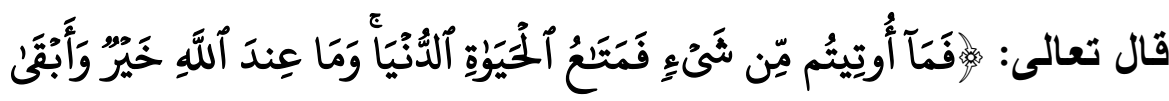

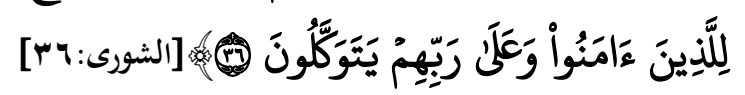

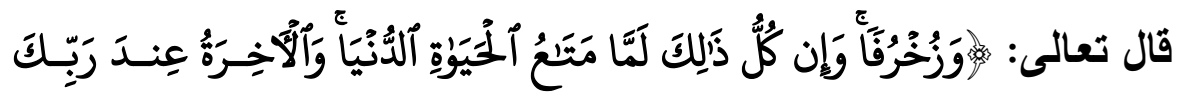

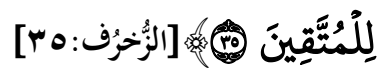

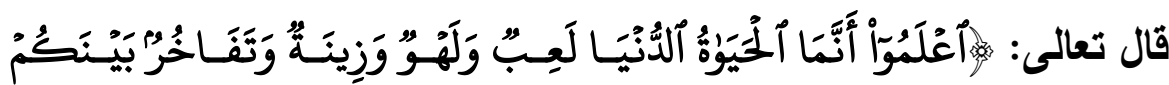

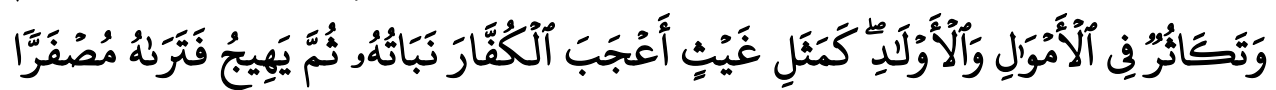

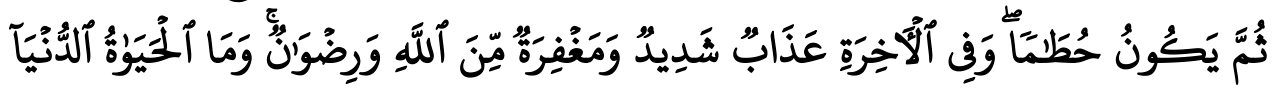

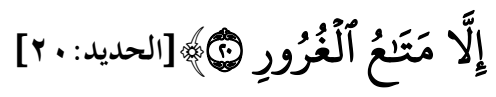

ويتأمل هذه الآيات نجد أنها يمكن تصنيفها في مجموعات حسب التثـابه بينها، وسأسسعى جاهدة في هذا المبحث إلى بيان الأسـرار البلاغيـة في ضـوء متثابه النظم لهذه الآيات، بعد حصرها، وتصنيفها إلى موضوعات متعددة بناء على مضمونها، وذكر ما جاء فيها من توافق واختلاف، وفق الآتي: 


\section{المطلب الأول: الحيساة هتساع الغـرور}

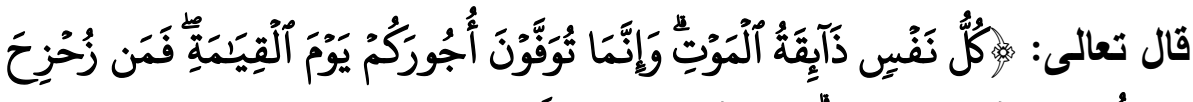

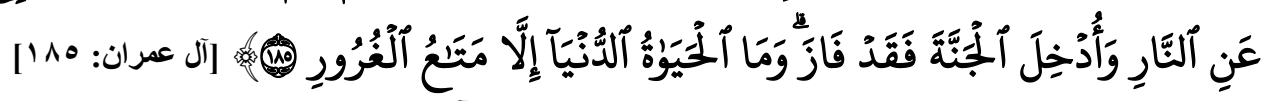

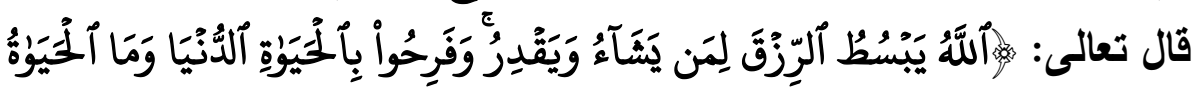

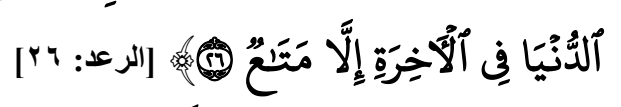

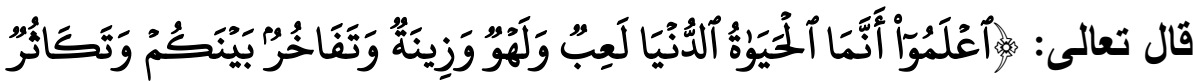

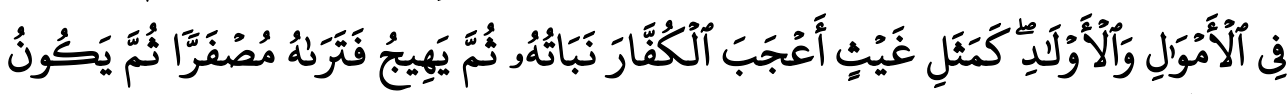

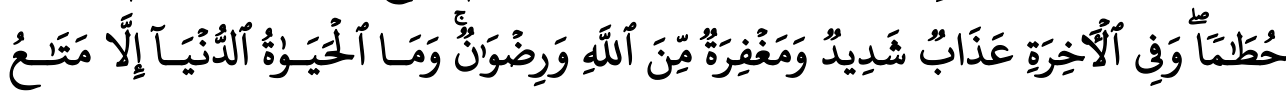

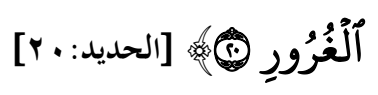

جاء التحذير من الدنيا بوصفها متاع الغرور، ويلحظ تطابق التركيب في قوله

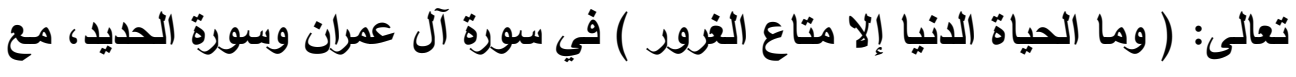

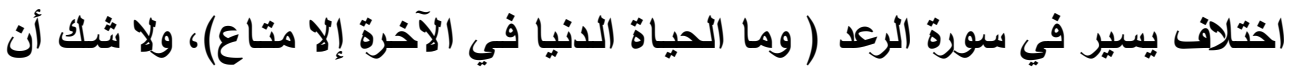

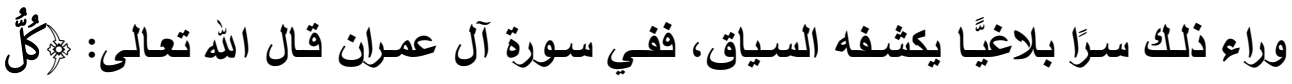

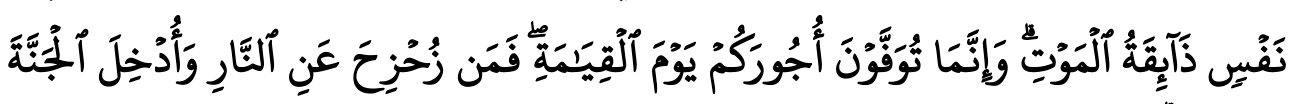

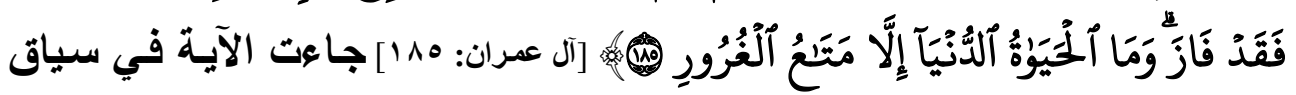

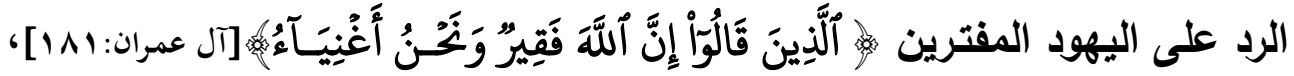

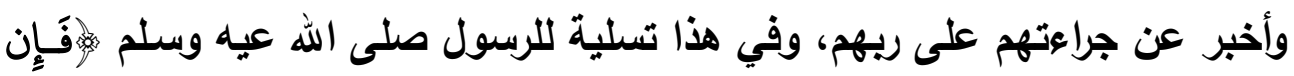

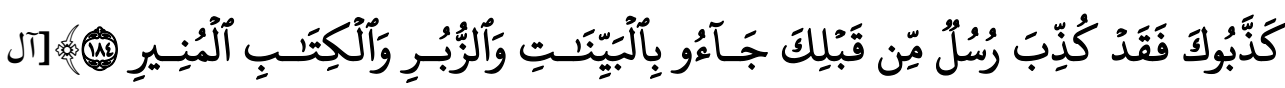

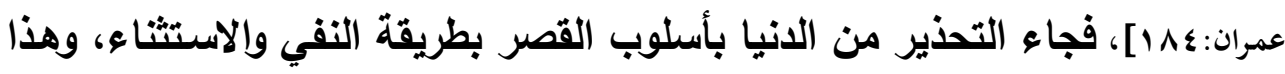
الأسلوب يلائم سياق الثكك والإنكار الصادر من اليهود، فالقصر بالنفي والاستثناء "

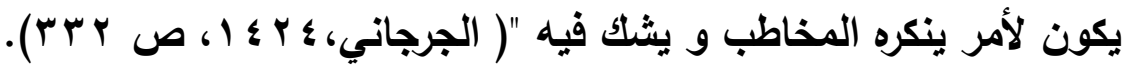

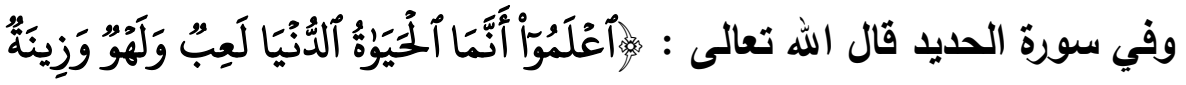

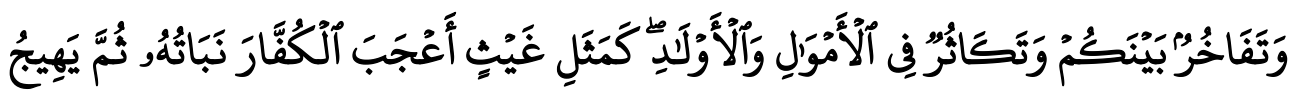




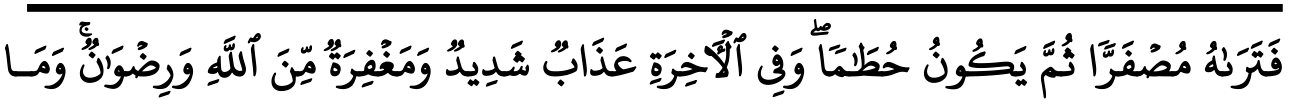

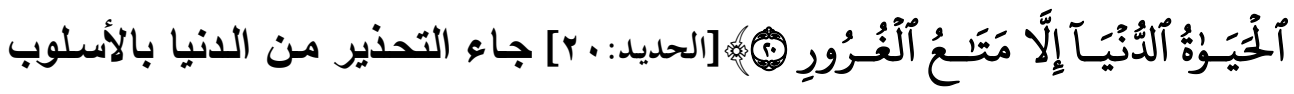

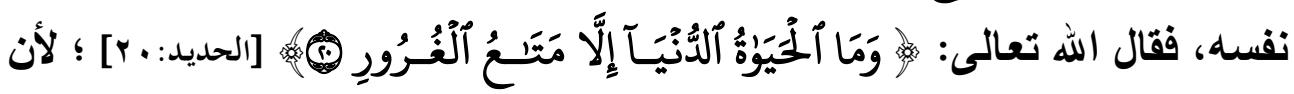

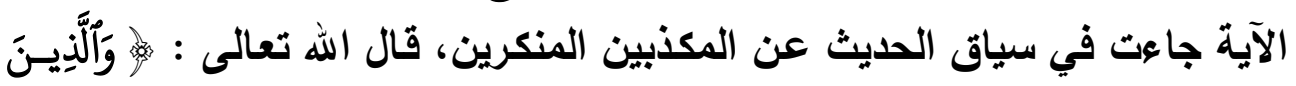

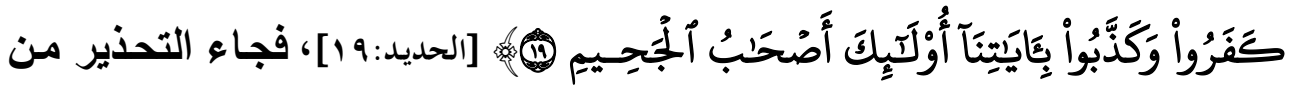

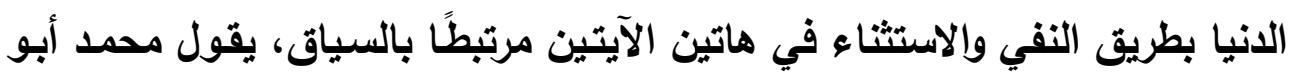

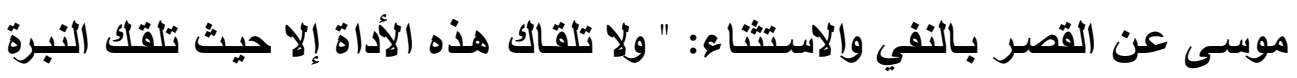

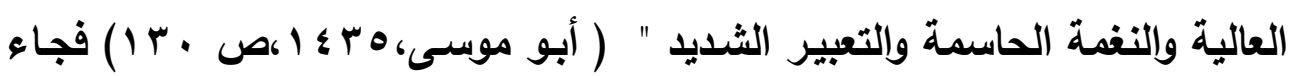
التعبير وفق حال المخاطب المنكر الثاك.

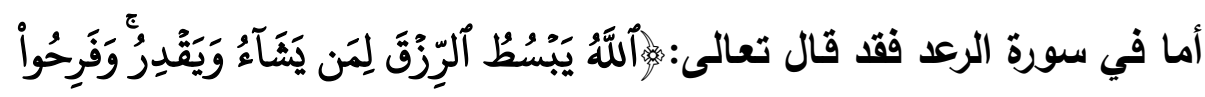

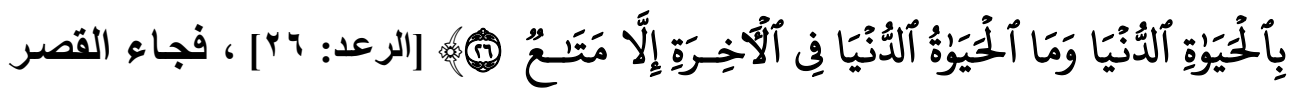

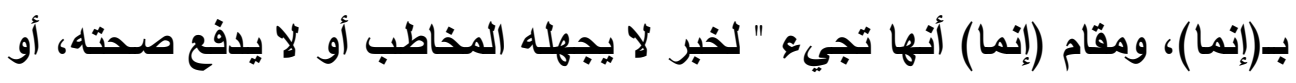

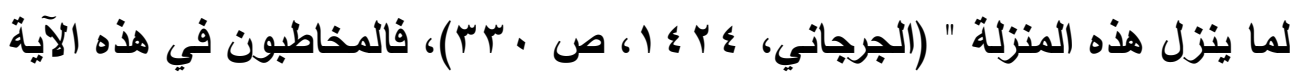

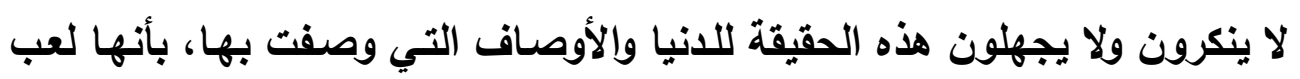

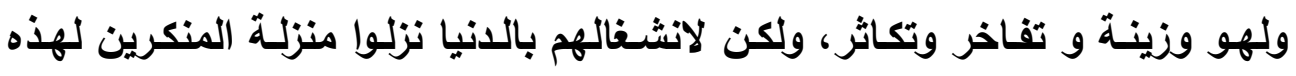

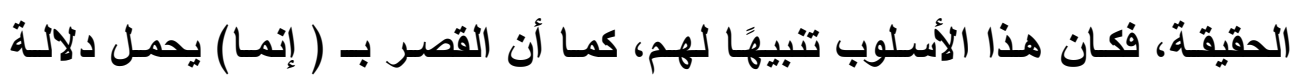

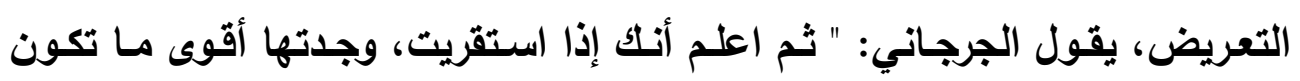

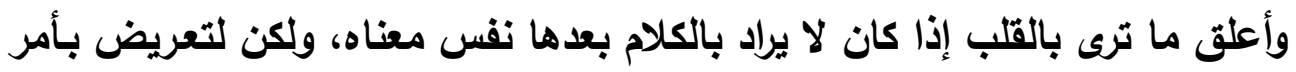

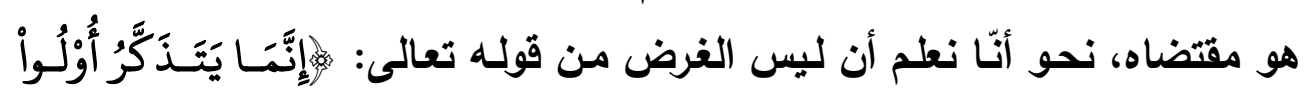

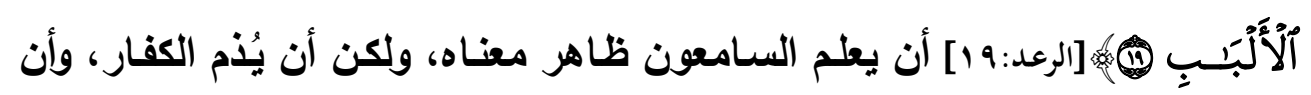

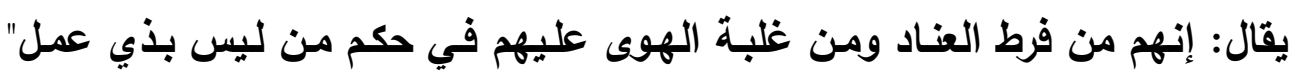

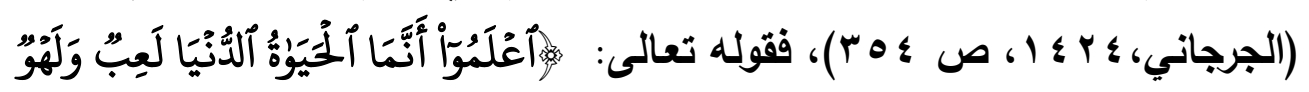

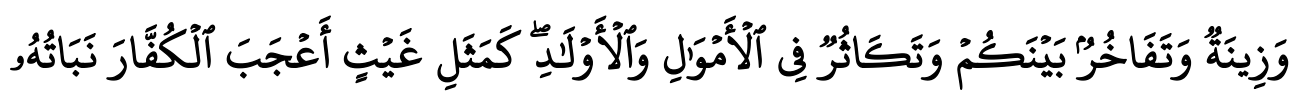




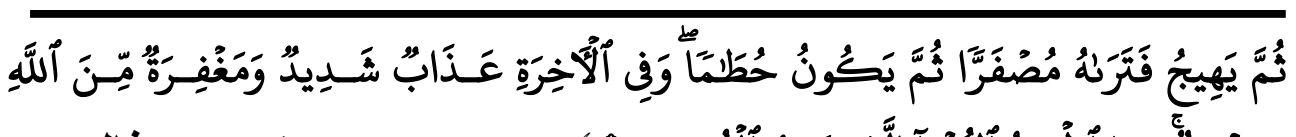

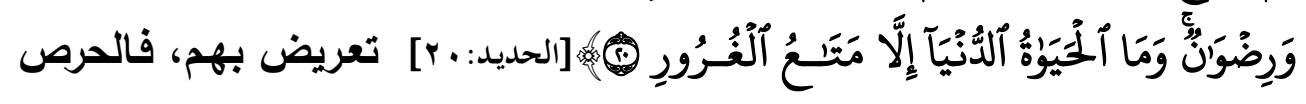

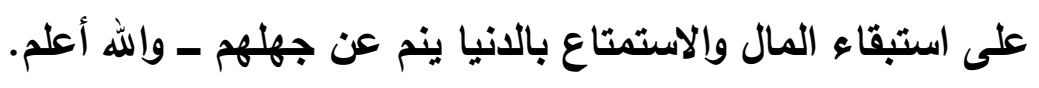

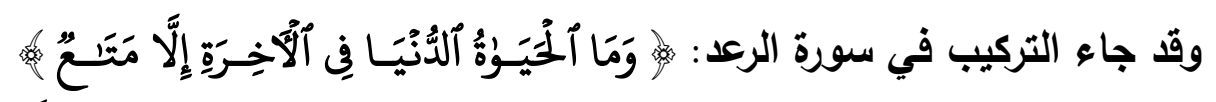

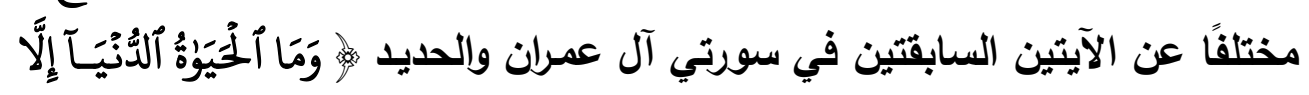

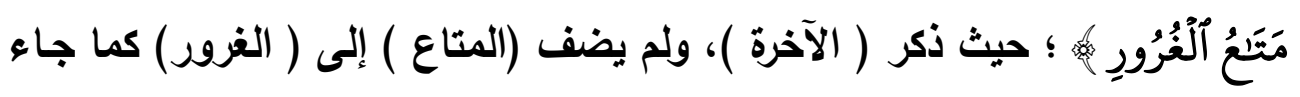

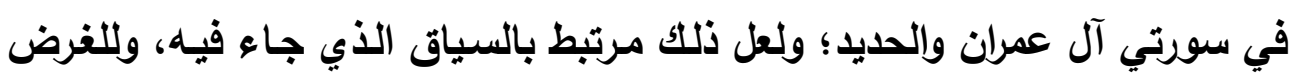

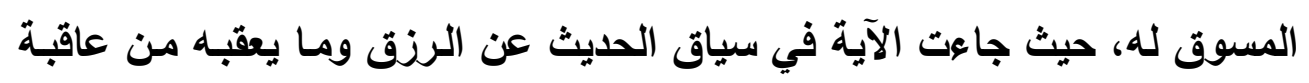

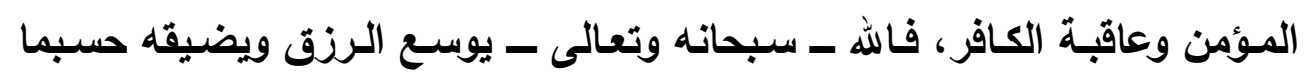

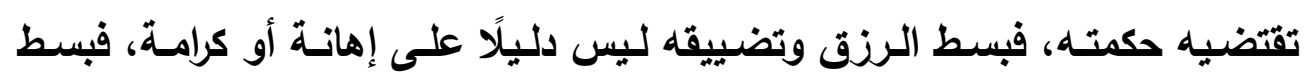

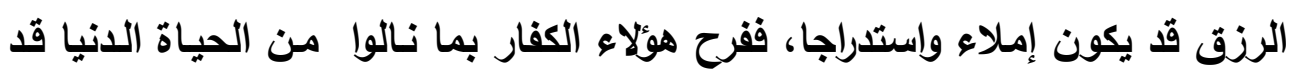

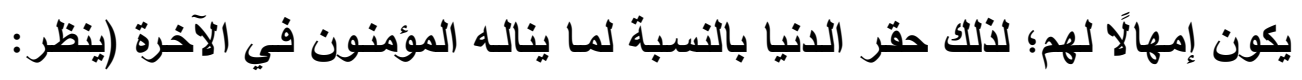

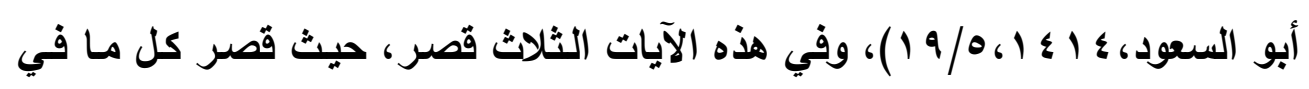

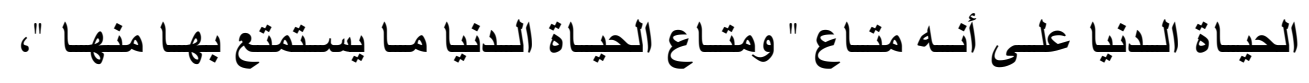

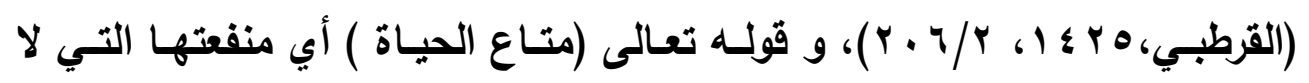

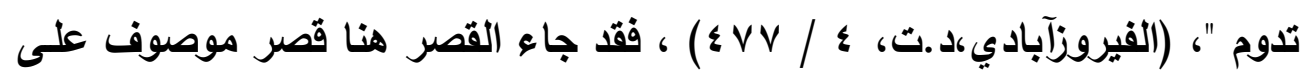
صفة، فالاختصاص هنا جاء في الخبر ( متاع ).

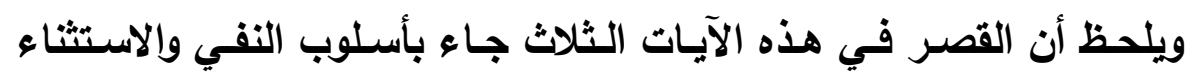

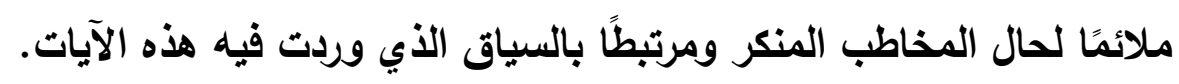
المطاب الثاني: المتاع قليل

سبق الحديث عن معنى المتاع في المبحث السـابق، وقد جاء موصـوفًا

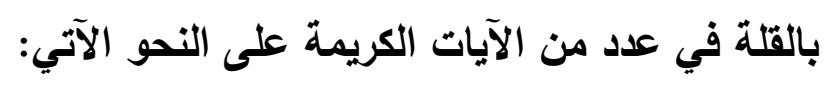

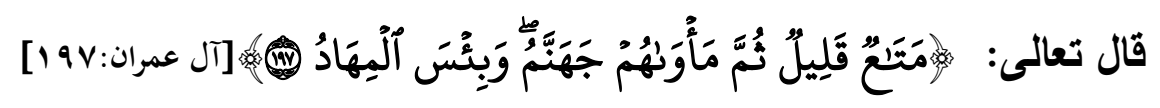




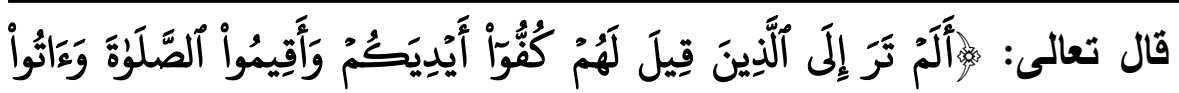

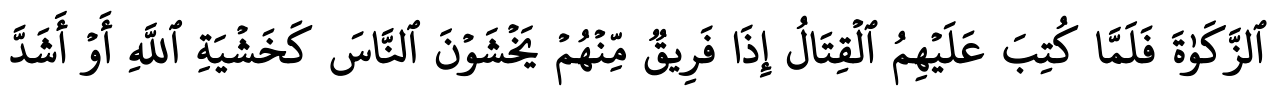

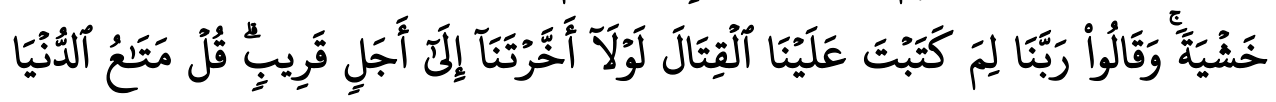

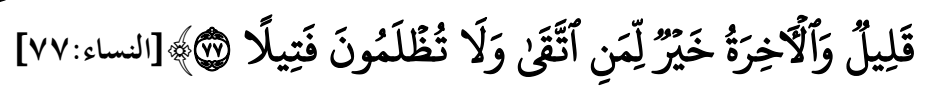

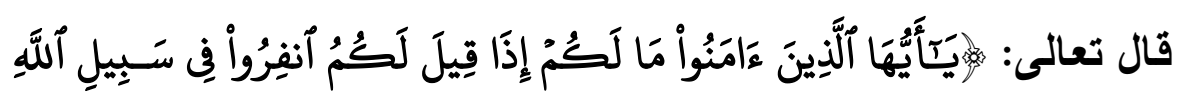

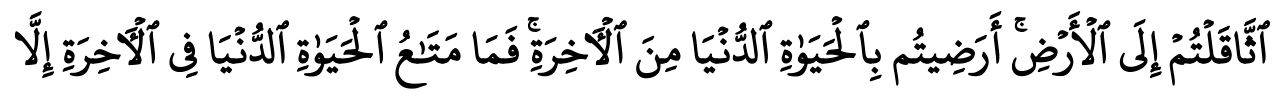

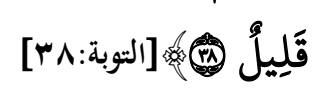

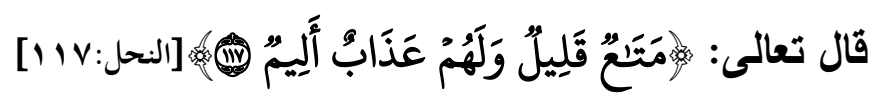

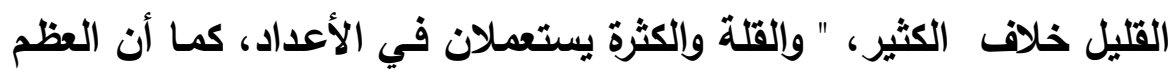

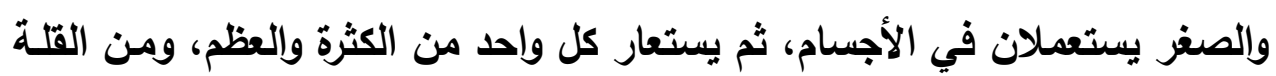

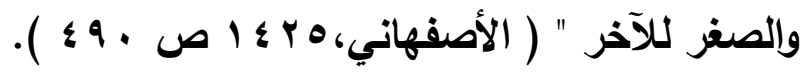

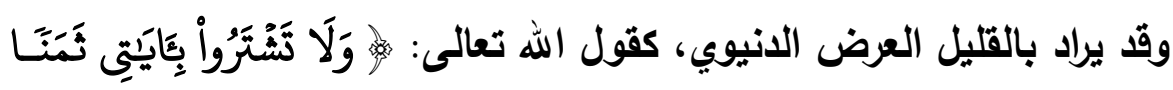

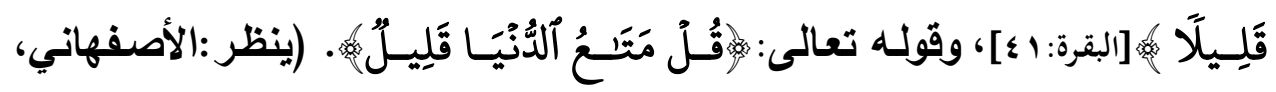

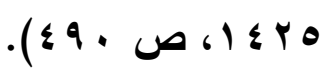

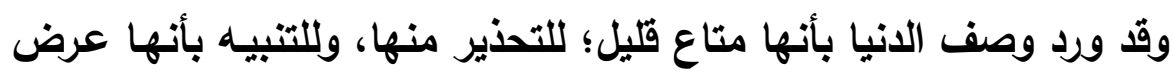
دنيوي زائل في عدد من الآيات، منها:

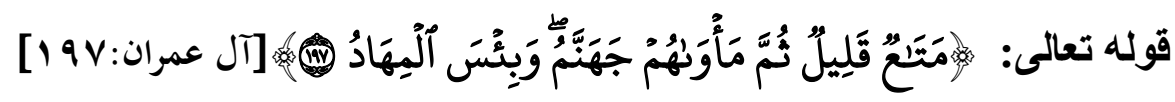

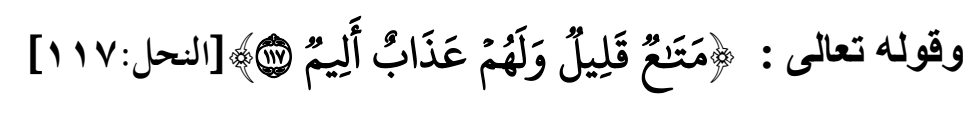

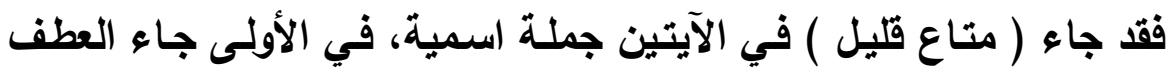

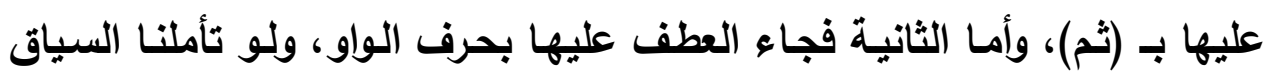

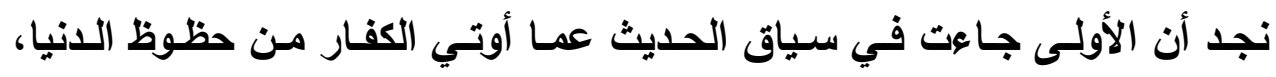
وحقارة شأنها إثر بيان ما أوتي المؤمنون من الثواب، فهو متاع قليل لا قدر لهـ الهان 


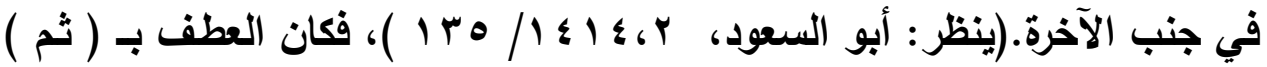

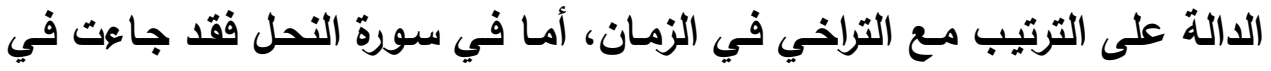

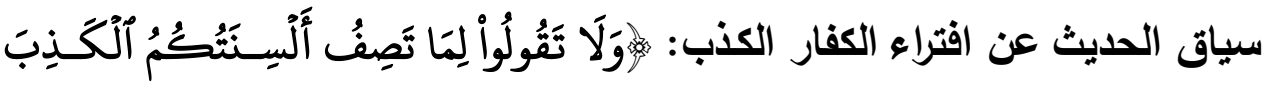

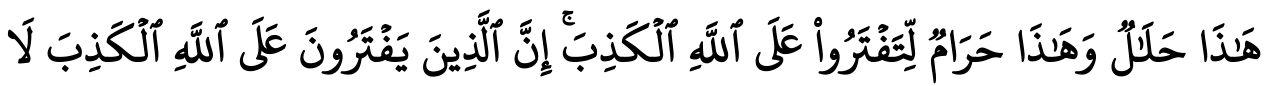

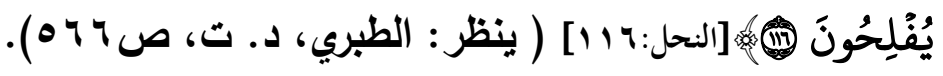

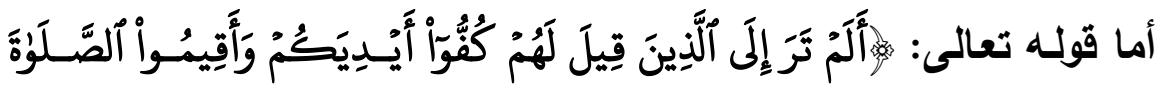

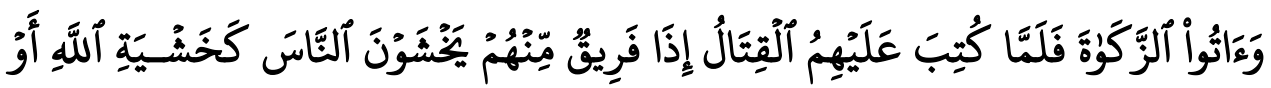

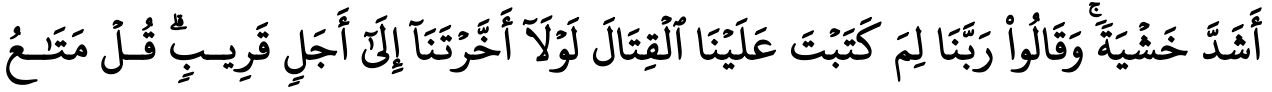

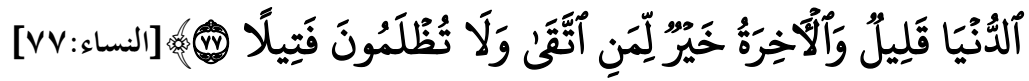

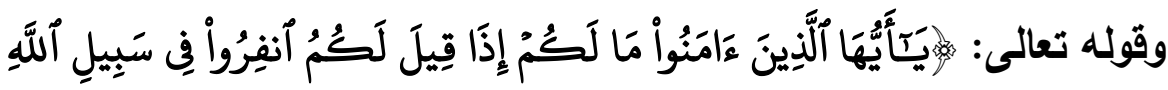

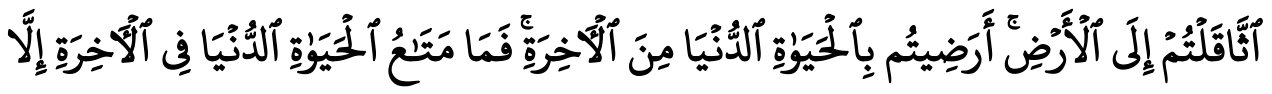

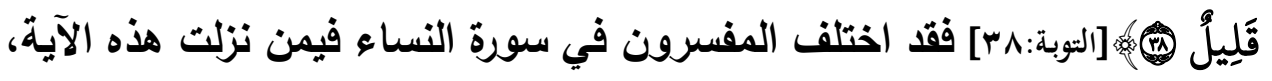

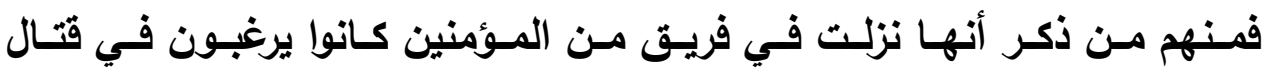

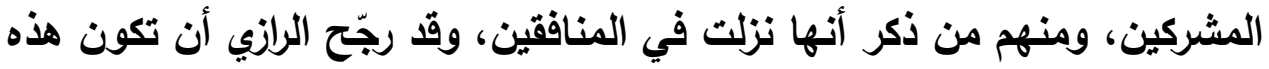
الآيـة صفة للمنـافقين، واستتل على ذلك بسياق الآيـة نفسـها، فقولـهـ تعالى:

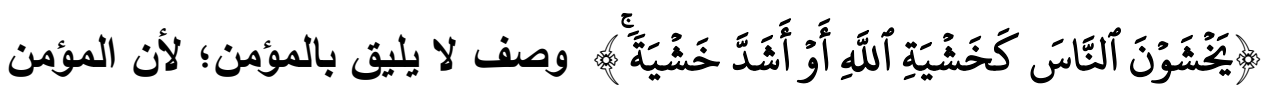

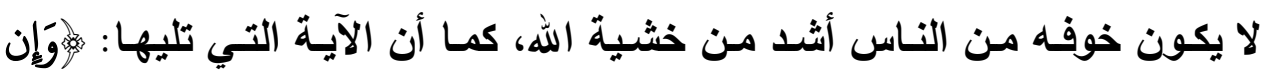

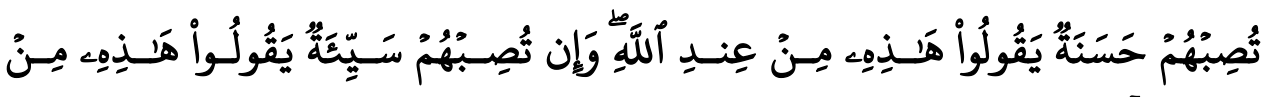

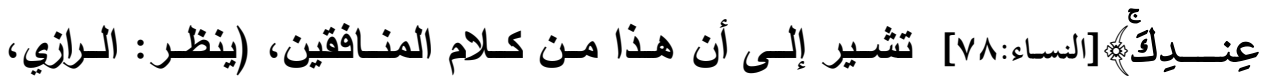

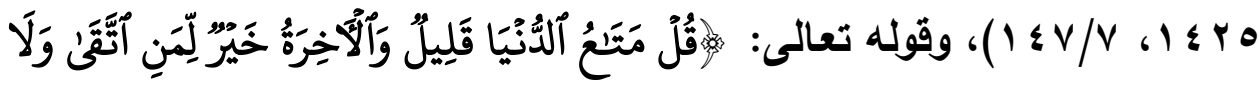

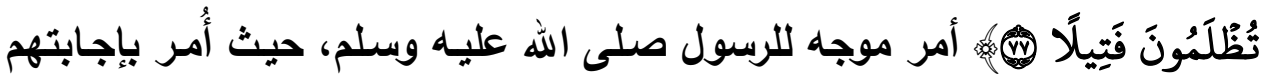

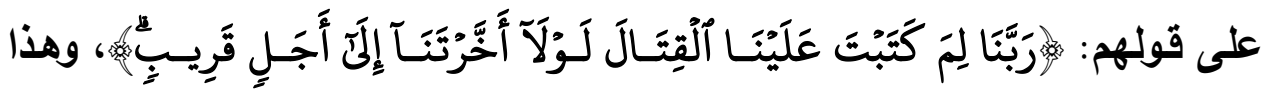


استفهام تعجبي، والفصل بين الجملتين لشبه كمال الاتصال، حيث جاءت الثانية

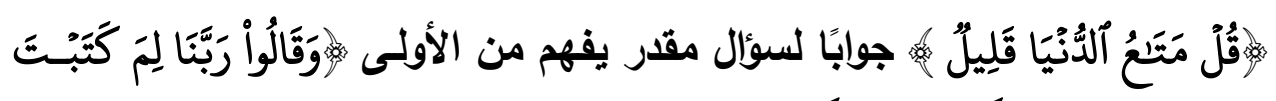

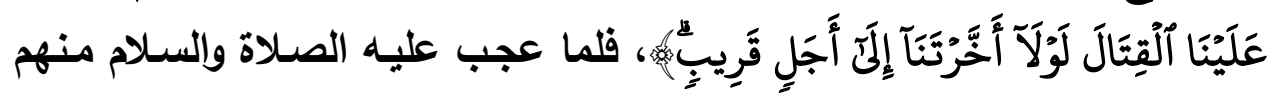

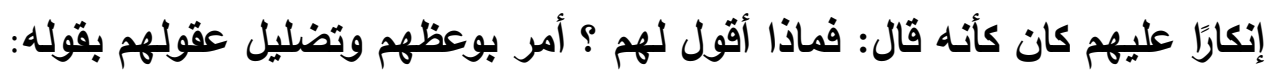

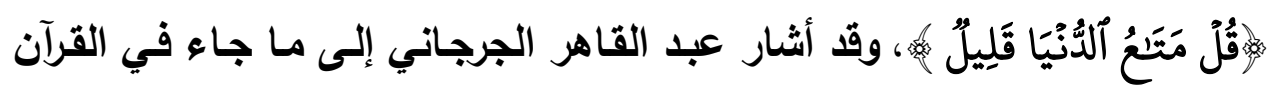

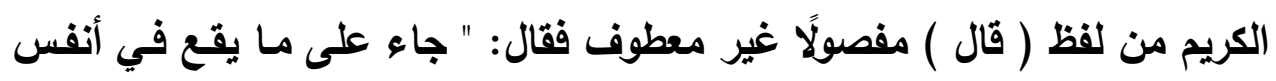

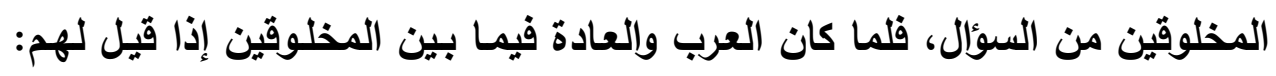

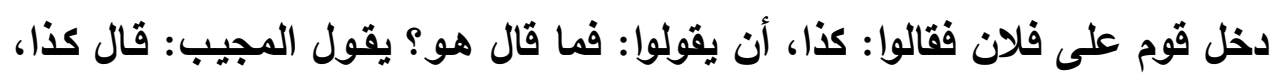

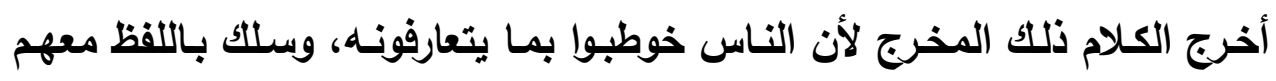

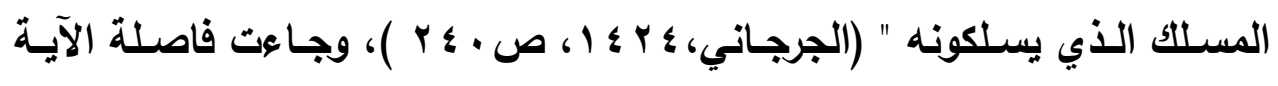

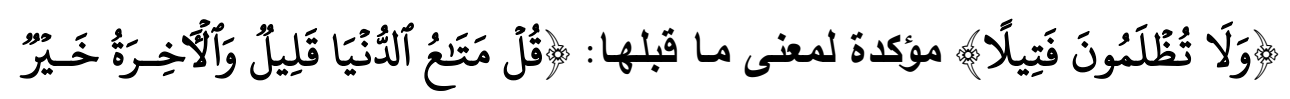

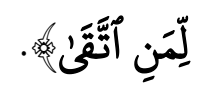

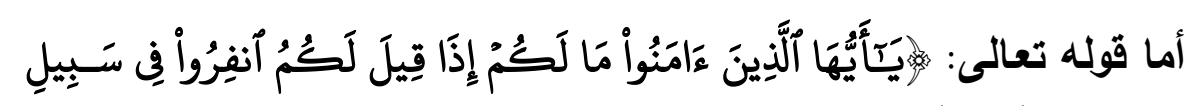

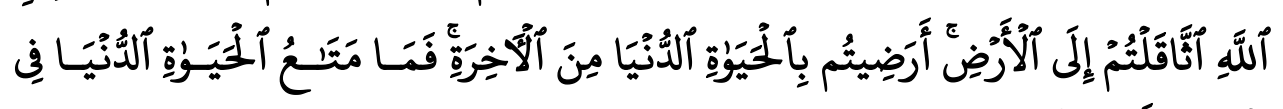

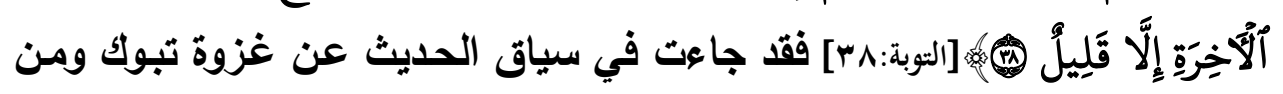

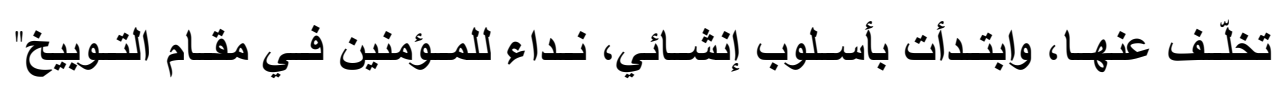

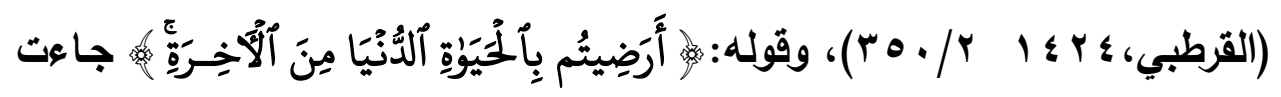

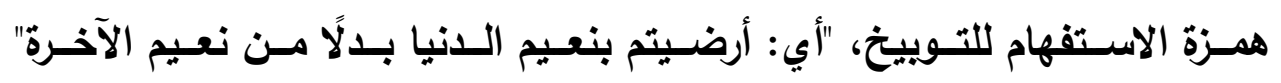

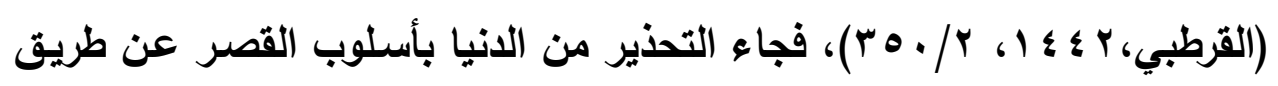

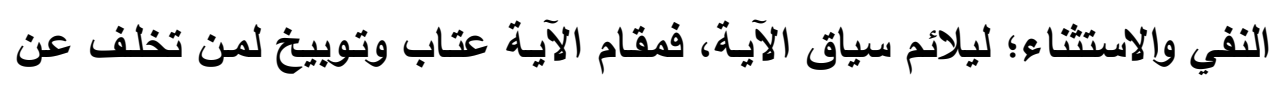

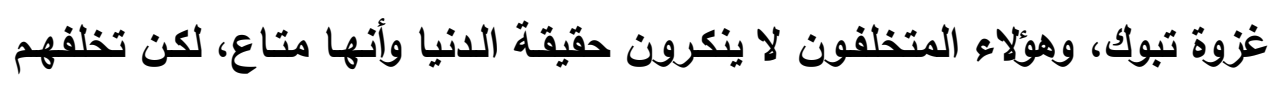

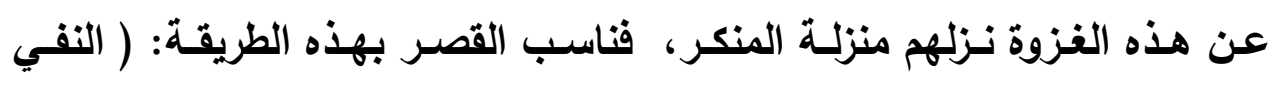

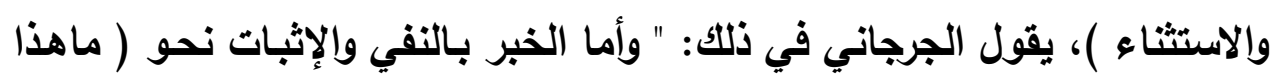


إلا كــا ) و( إن هـو إلا كـذا ) فيكـون لأمسر ينكـره المخاطب ويشــك فيـه "

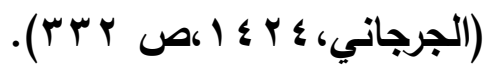
المطاب الثالث: هآل المتاع

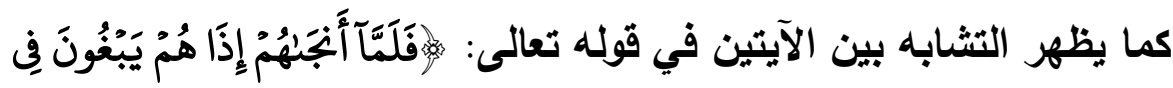

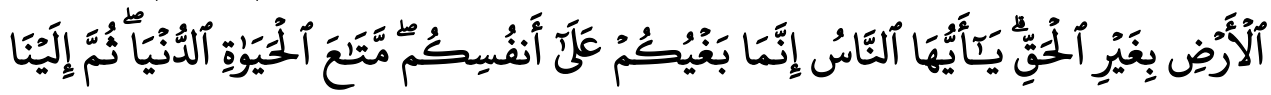

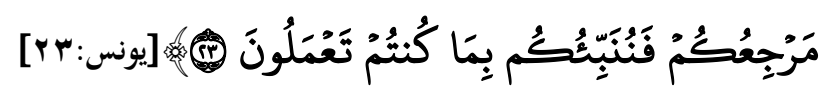

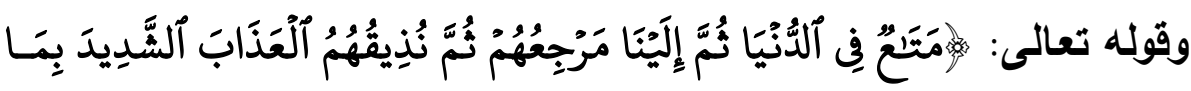

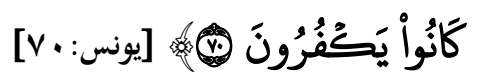

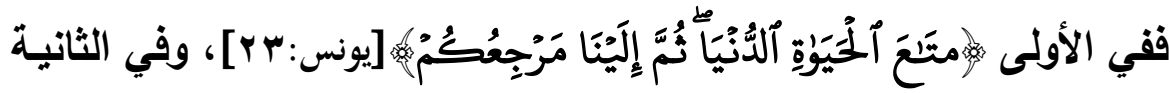

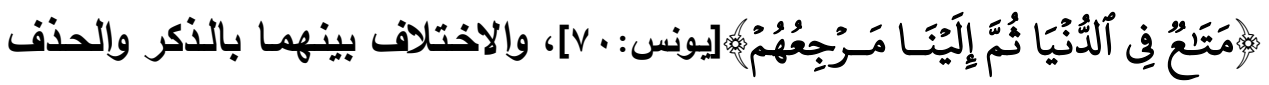

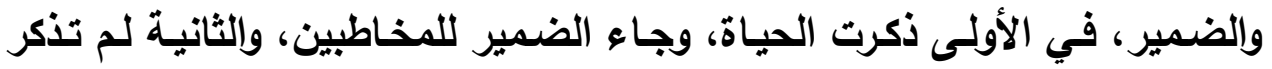

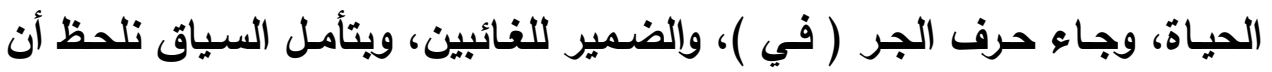

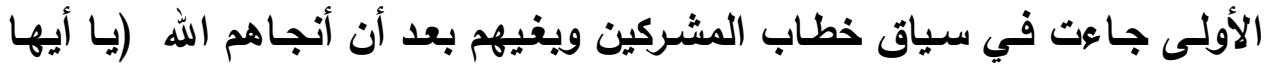
الناس إنما بغيكم على أنفسكم )، وتوجيه الخطاب إلى الباغين للتشديد في التهايد

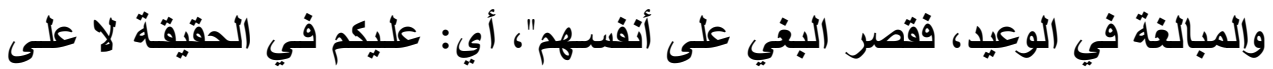

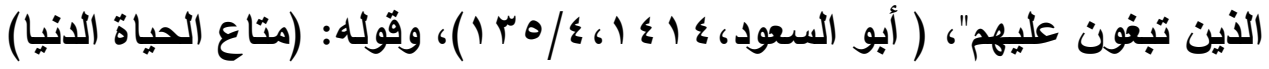

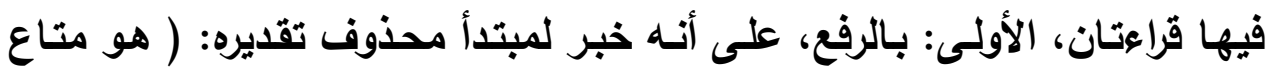

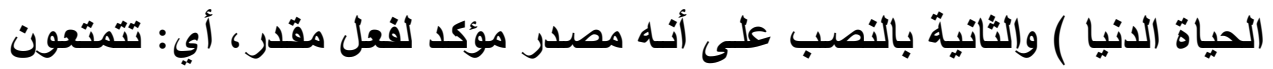

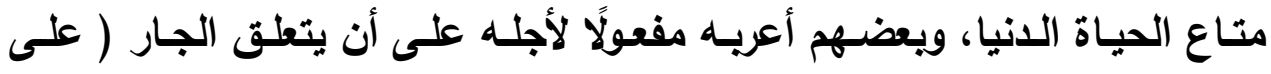

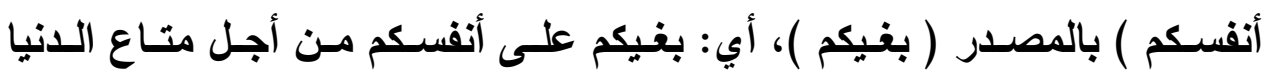

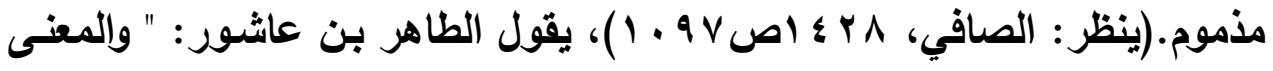

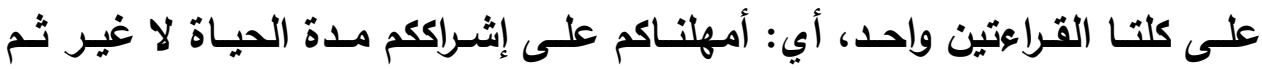


نؤاخذم على بغيكم عند مرجعم إلينا". (ابن عاشـور، د.ت 11 / / • ؛ 1)، وفي

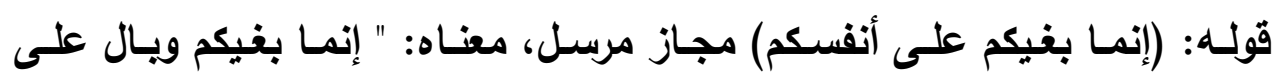

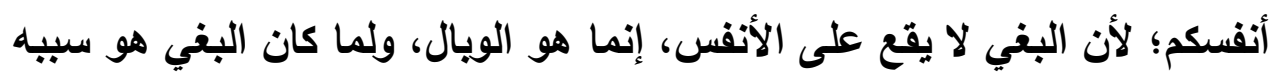

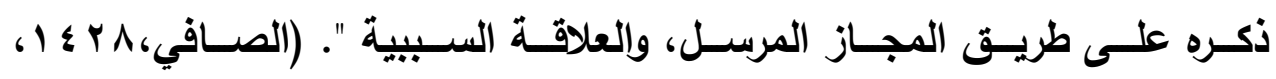

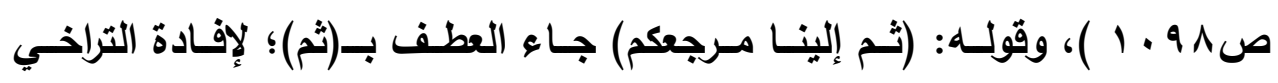

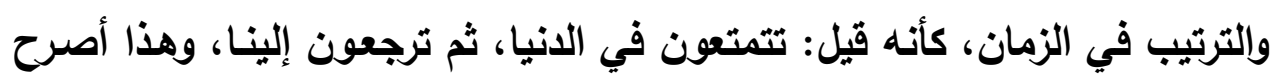

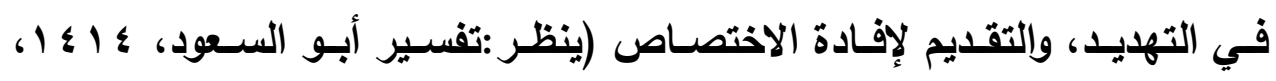
.$(1 \mathrm{mq} / \mathrm{s}$

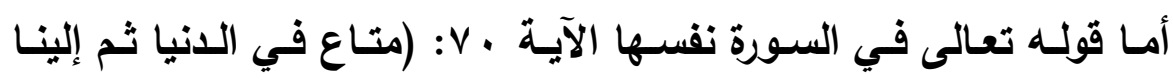
مرجعهم) فقد جاعت في سياق الذين افتروا على الله الكذب، والآية استئناف بياني

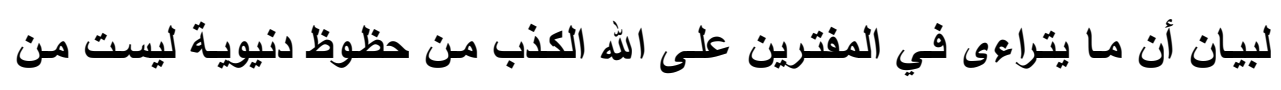

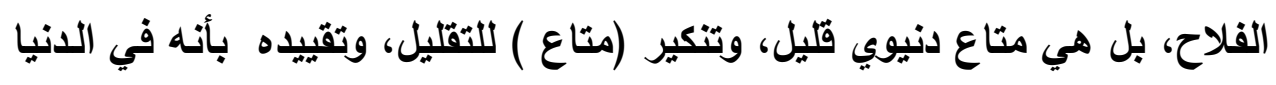

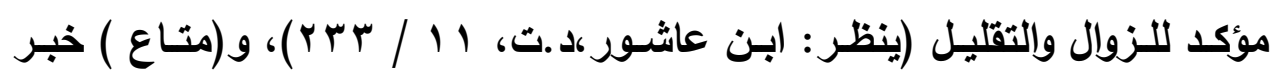

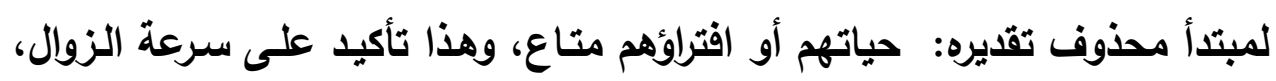

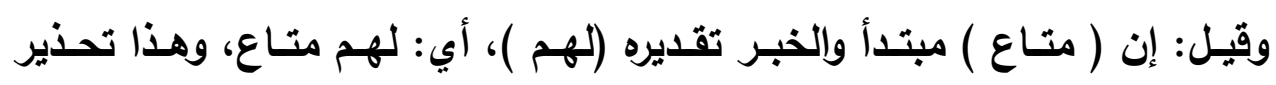

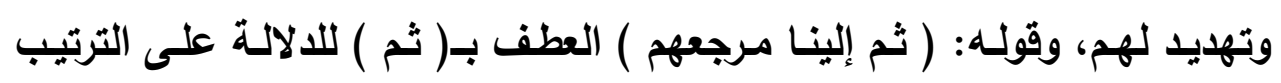

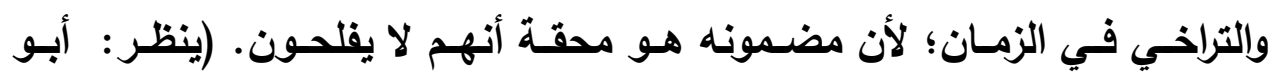

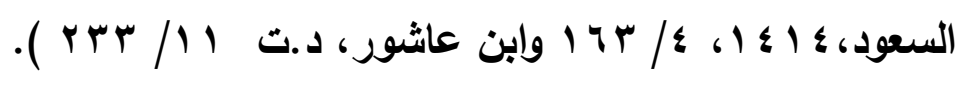

\section{المطاب الرابـع/ متساع الحيساة الدنيـا}

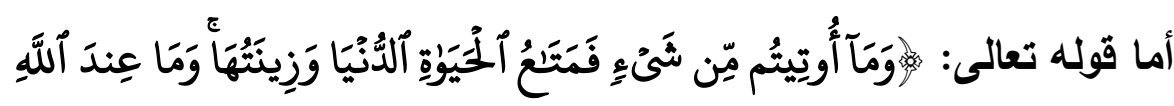

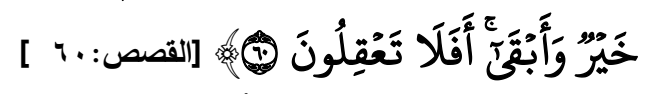

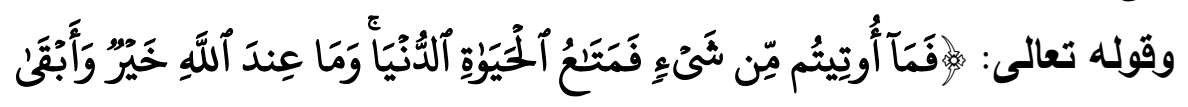

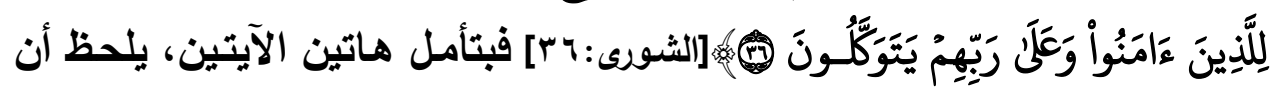


الأولى جاءت بالواو والثانيـة بالفاء، والأولى ذكرت فيها الزينـة، والثثانية لم تذكر

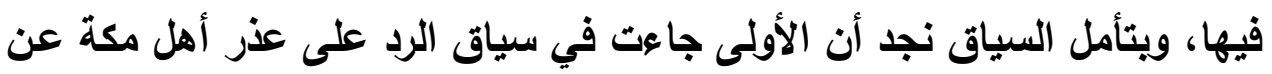

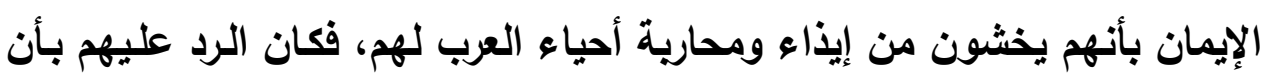

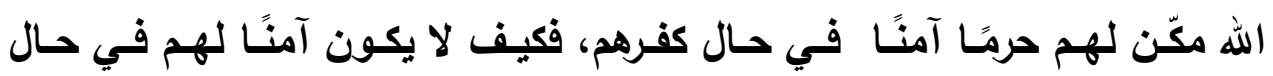

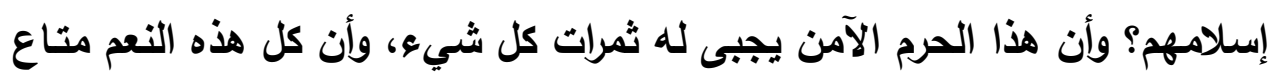

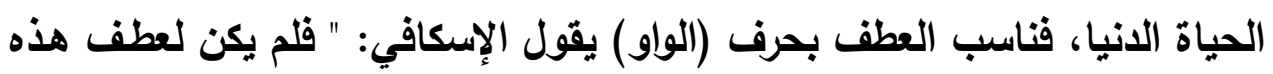

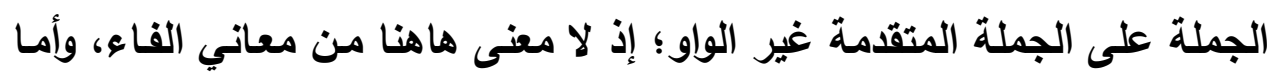

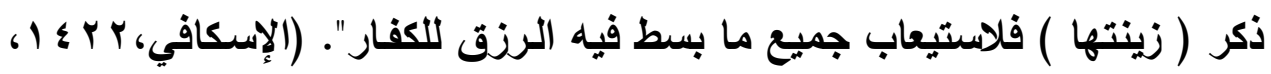

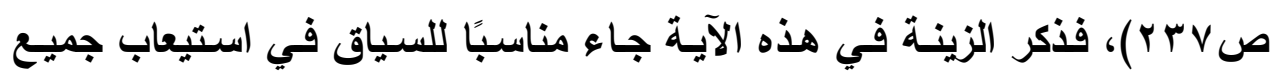

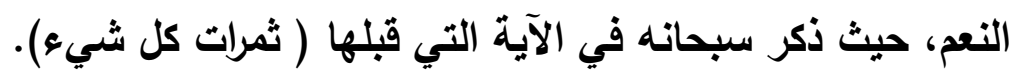

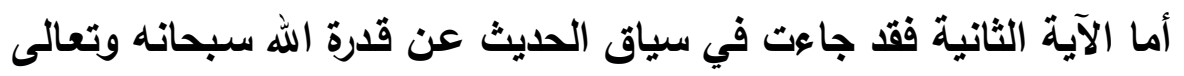

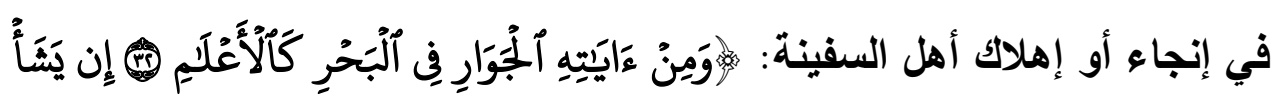

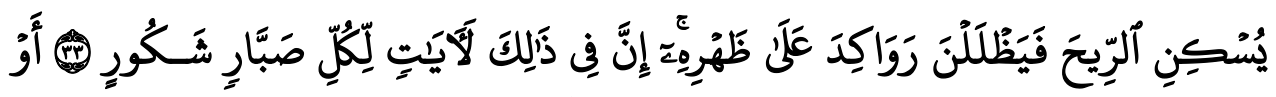

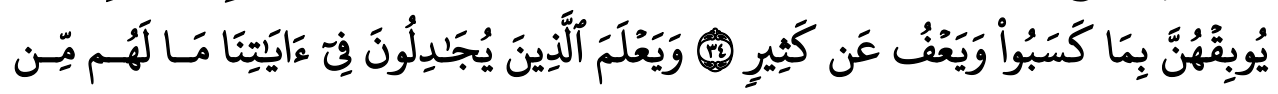

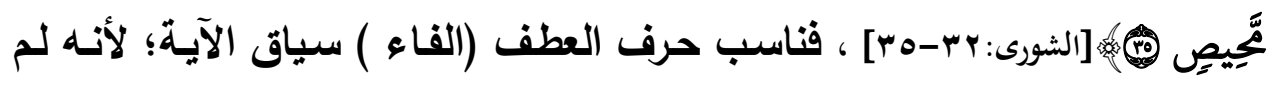
يقصد بها الاستيعاب كالآية السابقة، بل المقصود مطلويهم في تلكك الحالة، وهو

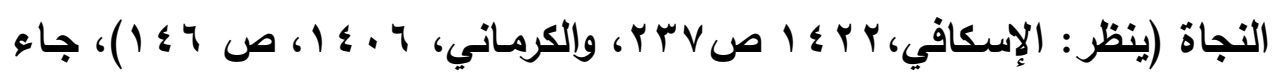

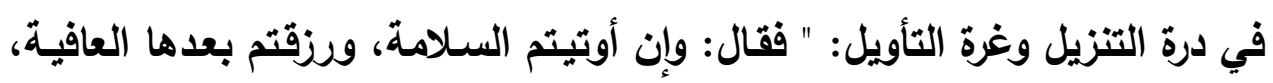

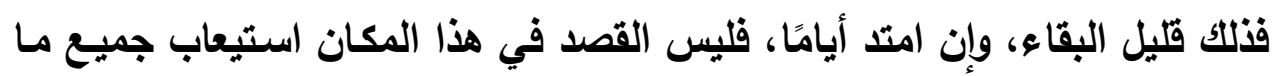

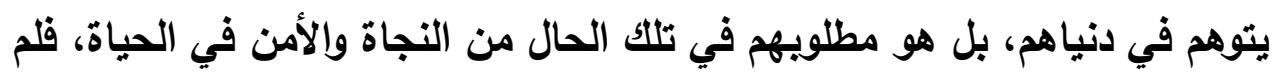

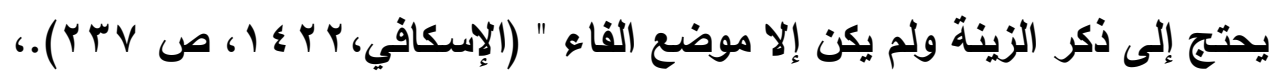

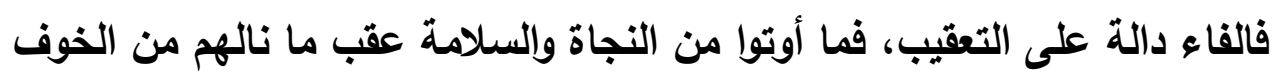
والوجل ما هو إلا متاع قليل. 


\section{المبــث الثانـي

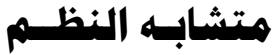

فـي الآيـات الدالـة عالـى أن الدنيـا لهـب ولهـو وغـرور

المطالب الأول: الدنيسا لعبب ولهــو

جاء التحذير من الدنيا بوصفها لعبًا ولههوًا في عدة مواضـع مـن القرآن

الكريم كما سيأتي بيانـه، واللعب: طلب الفرح بما لا يحسن أن يطلب بـه، وقيل:

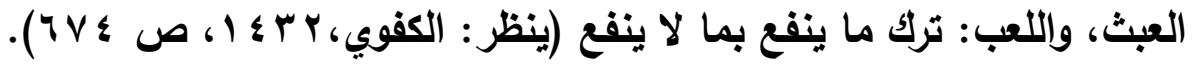
أمـا اللهو، فهو " مـا يشـل الإنسـان عمـا يعنيه ويهمـه، يقال: لهوت بكذا

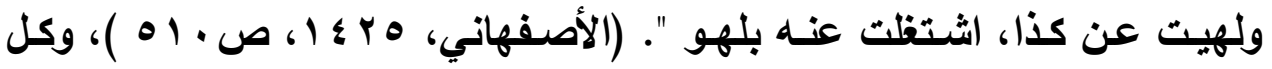

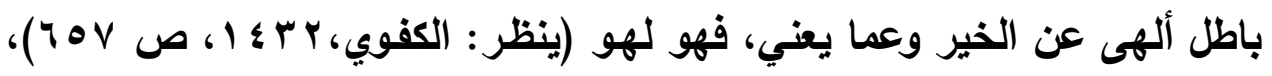
وذكر اللدامغاني أن اللهو جـاء على سـتة وجوه: (السـخرية والاستهزاء، الولد،

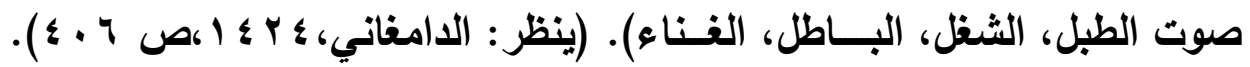
وقد جاء ( اللهو ) في عشرة مواضع في القرآن الكريم على هذه الوجوه،

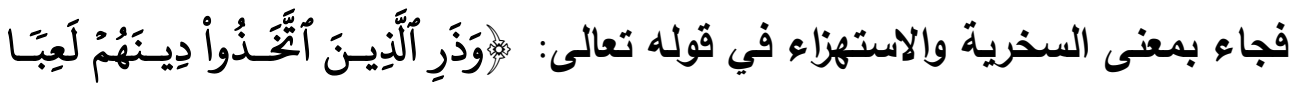

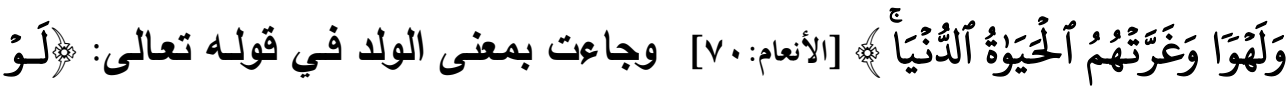

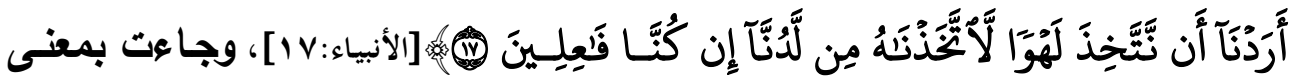

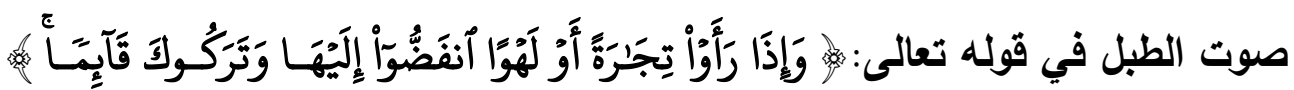

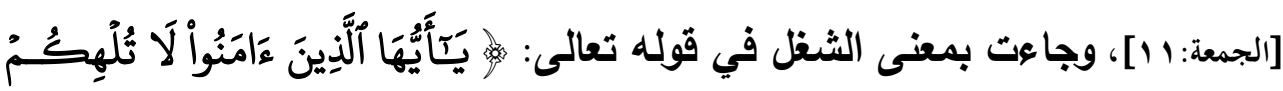

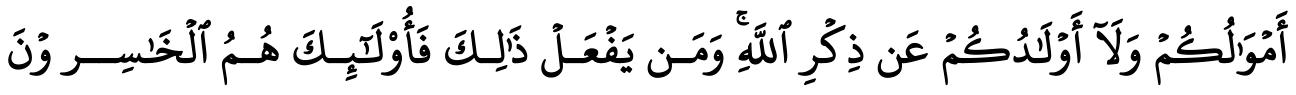

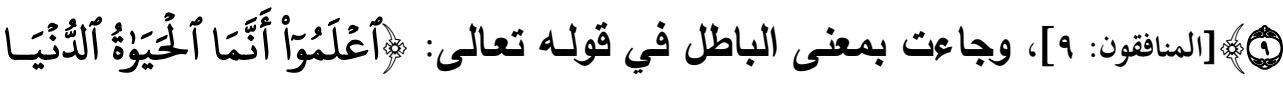

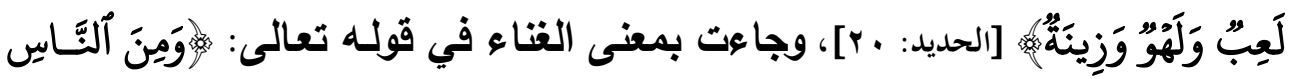

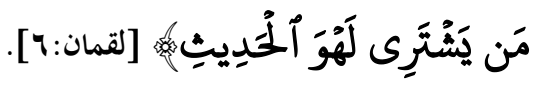


وقد ورد هذين اللفظين في القرآن الكريم في سياق التحذير من الدنيا، في

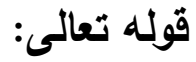

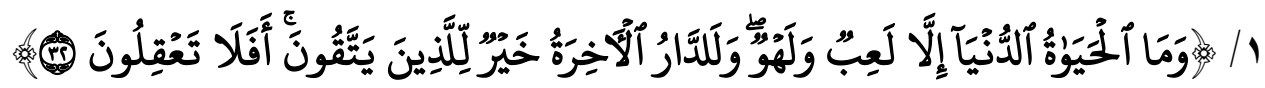

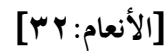

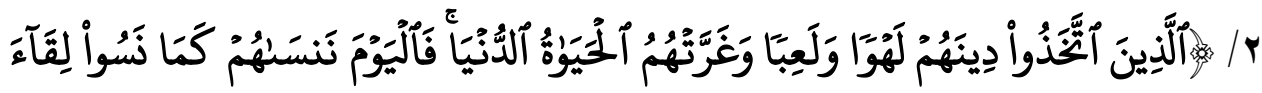

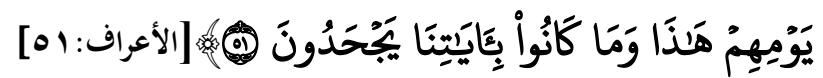

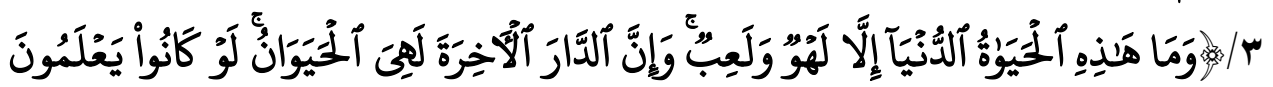
[ب]

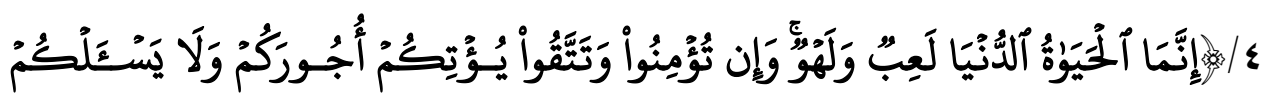
أَمْوَلَكُعْم

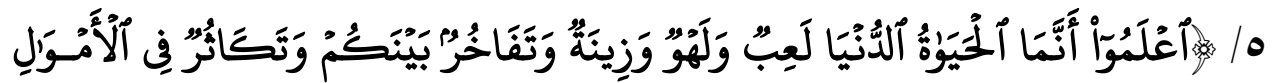

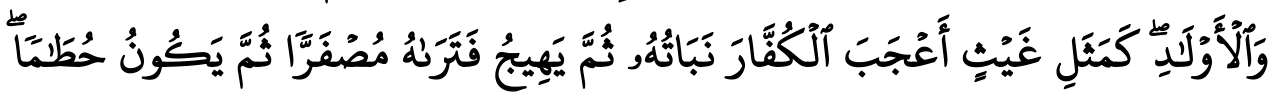

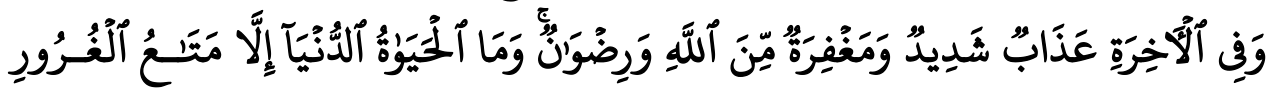

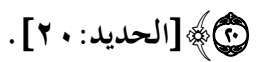
بتأمل هذه الآيـات الكريمـة نلحظ أنـه في سـورتي الأعراف والعنكبوت قدم

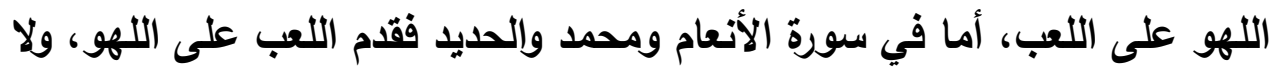
شك أن هذا الاختلاف في التركيب جاء من السياق الذي وردت فيه هذه الآيات،

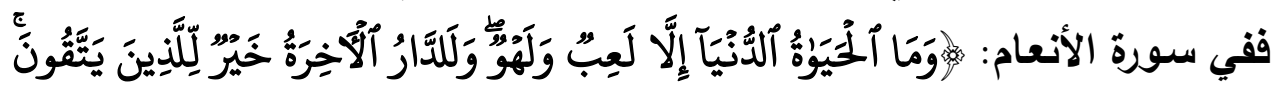

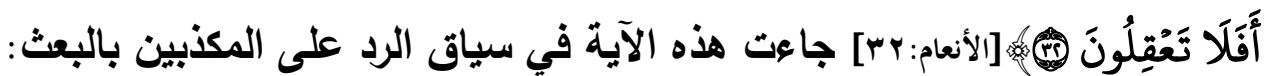

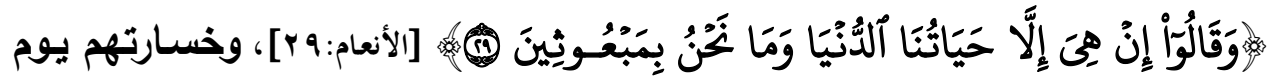

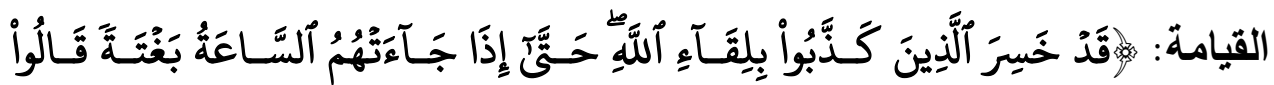

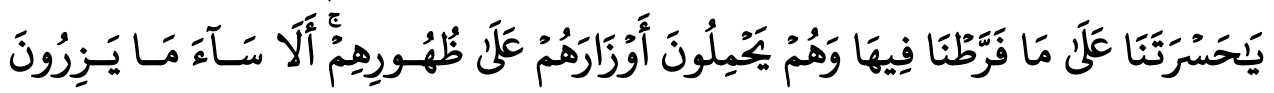

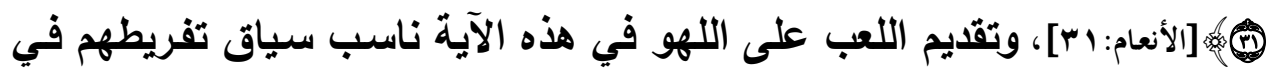


الانيا وقلة عقولهم، فاللعب "عمل أو قول في خفة وسرعة وطيش ليس لـه غاية مفيدة، بل غايته إراحة البال وتقصير الوقت واستجلاب العقول في حالة ضعفوله ولها

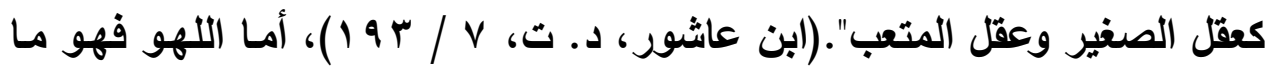
يشظل الإنسان عما يعينه ويهمه، يقال: لهوت بكذا ولهيت عن كذا، اشتظلت عنه

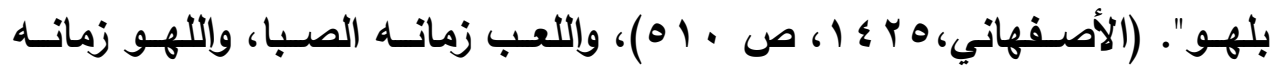

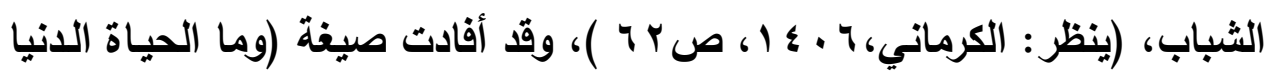

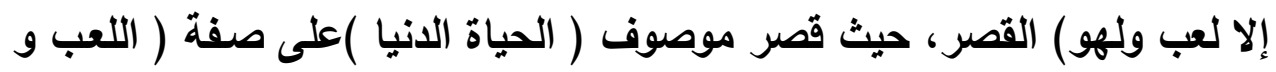
اللهو) وقث يكون الغرض من هذه الصيغة التأكيد على قصر مدة الانيا، وأن كل

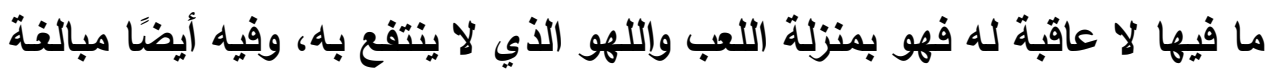

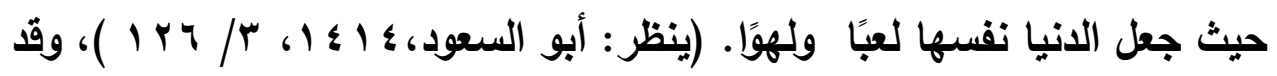

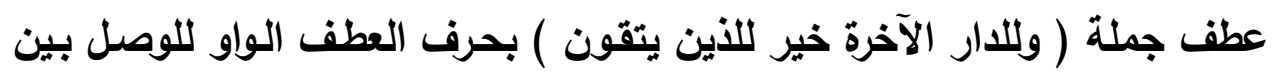

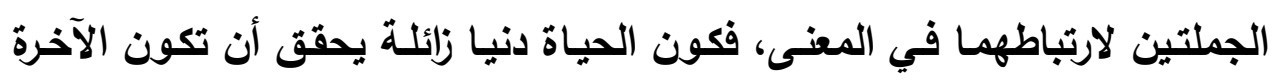

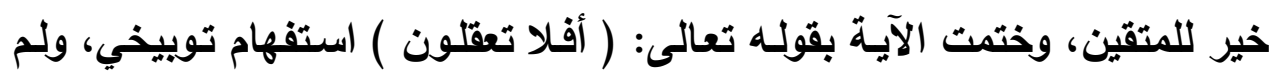

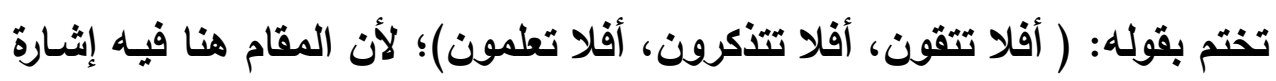
إلى قلة عقولهم وتفريطهم في دنياهم، والله أعلم.

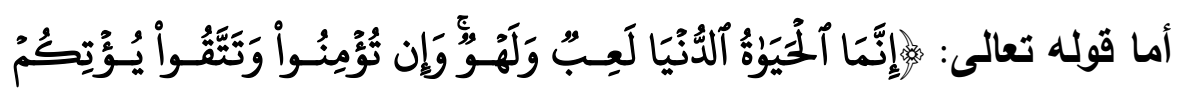

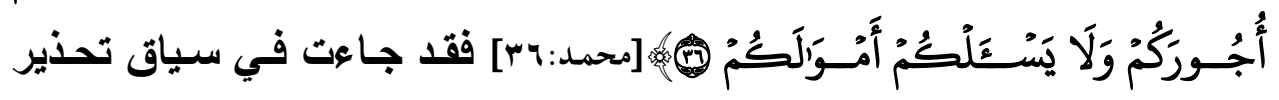

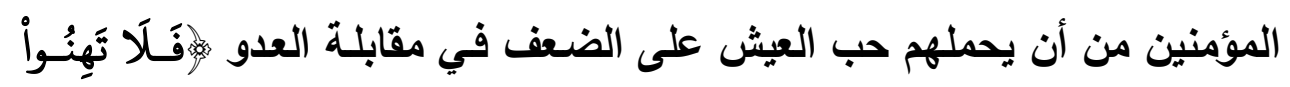

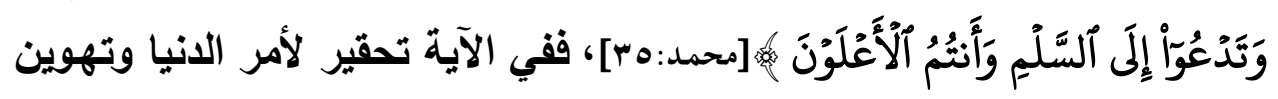

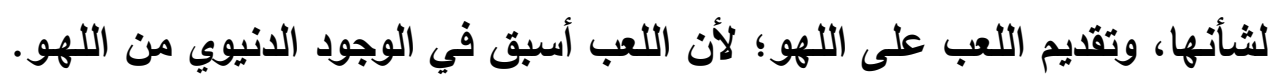

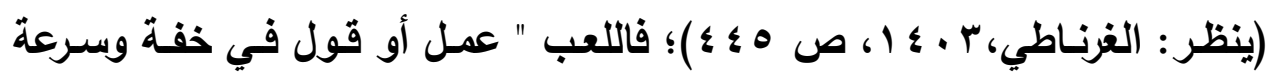

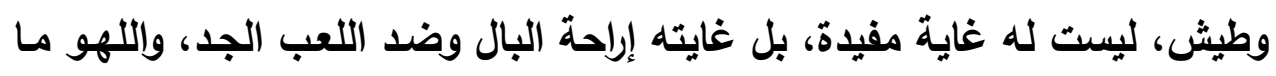

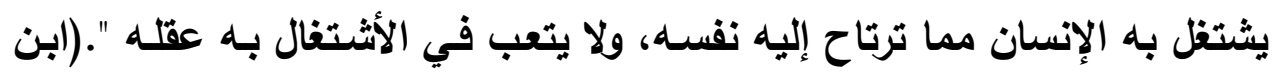




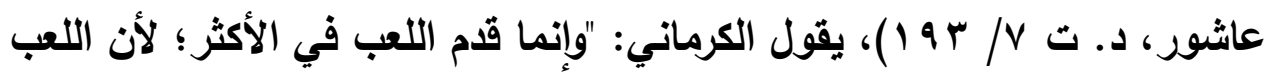

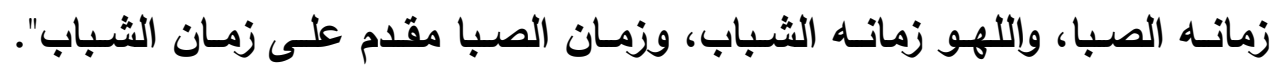

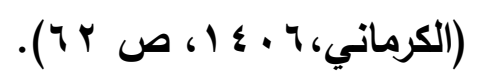
وقد جاء القصر بـ( إنما)، وقصر الحياة الدنيا على اللعب واللهو للإثـارة

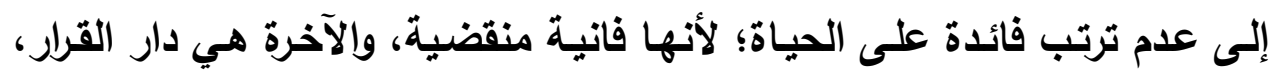

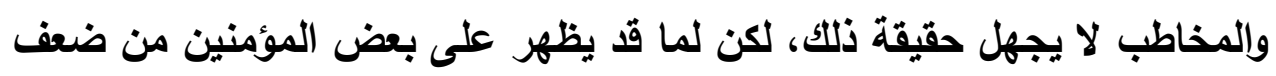

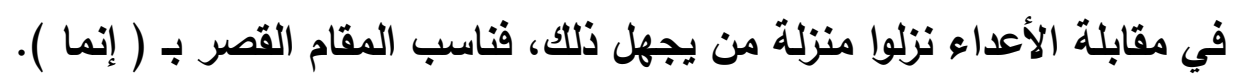

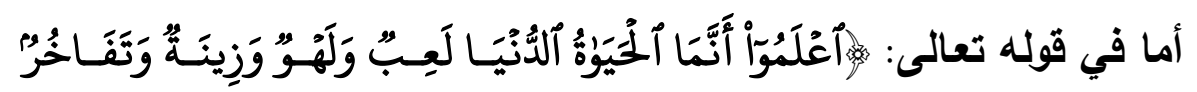

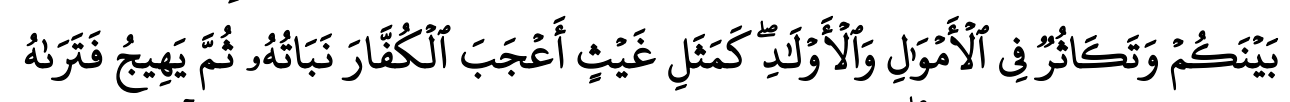

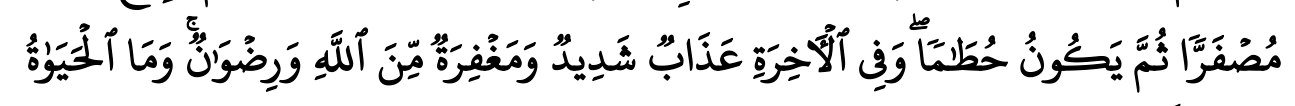

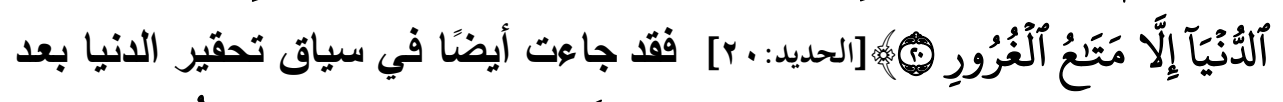

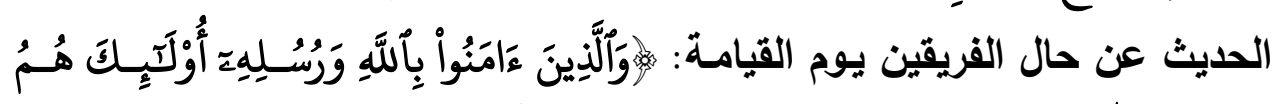

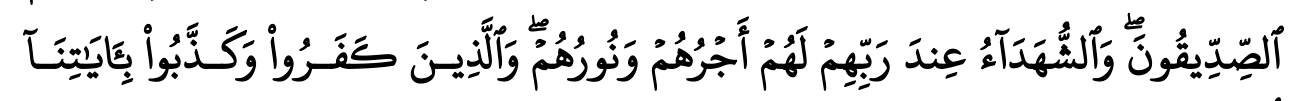

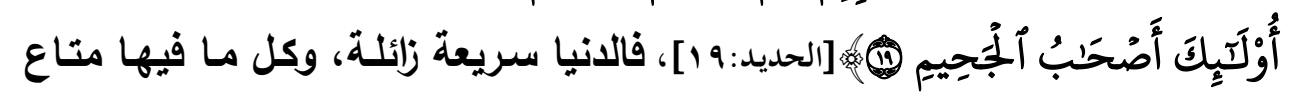
قليل، وقد جاء ترتيب هذه الألفاظ ( لعب ولهو وزينـة وتفاخر بينكم وتكاثر في

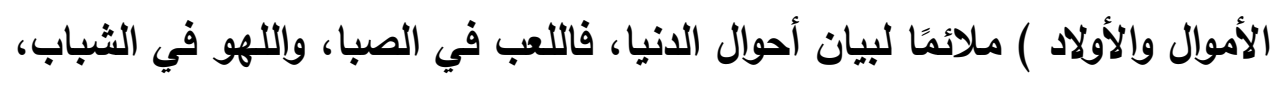

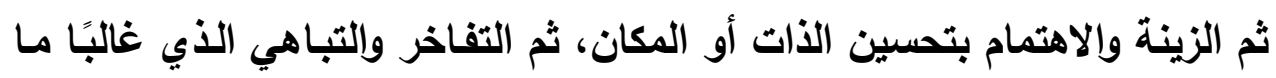

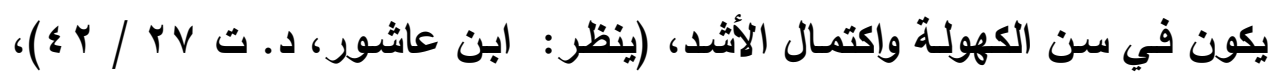

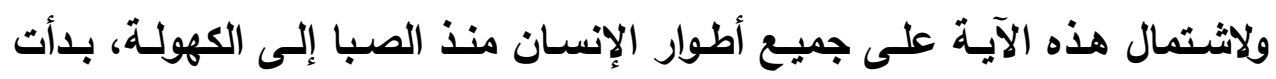

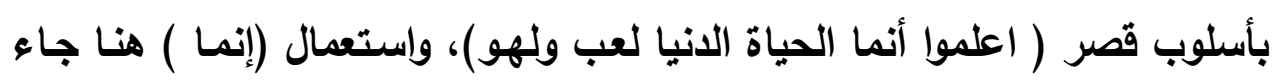

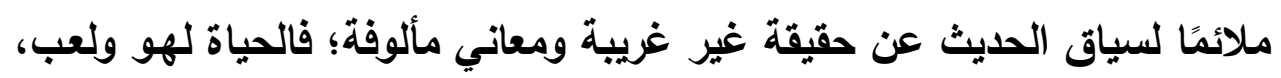
ولمـا جاء السياق تحذير وتهديد ناسب استعمال النفي والاستثناء:( ومـا الحياة

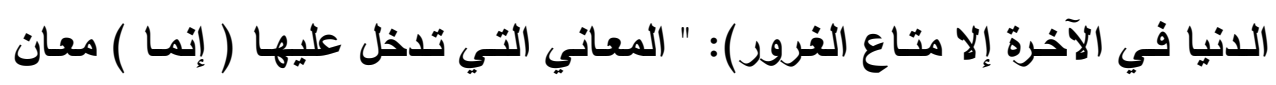


مأنوسة قريبة من النفوس، فلا تلخل على الحقائق الغريبة والأفكار البعيدة، هذا

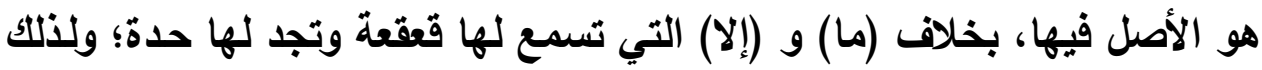

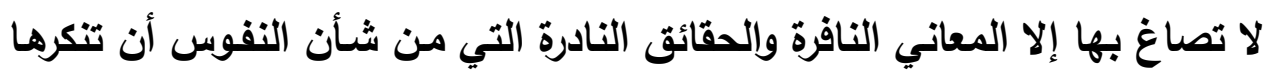

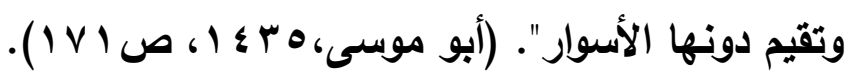

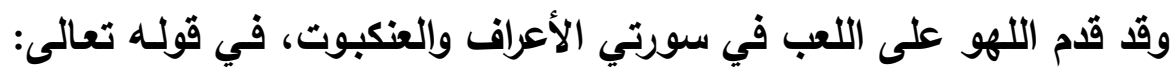

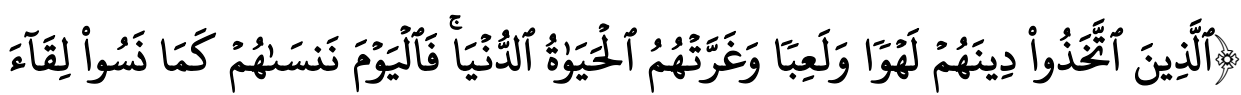

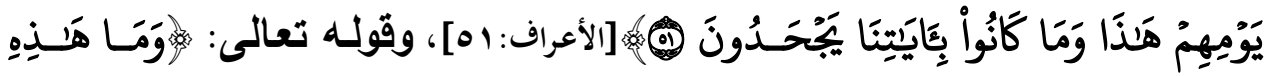

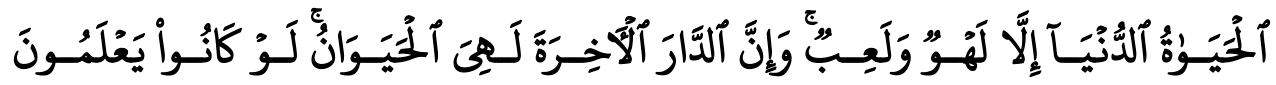

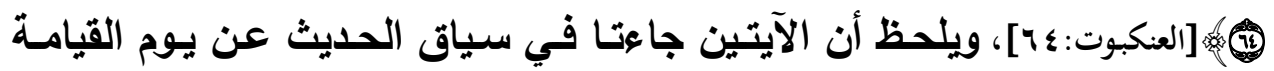
ومواقف الآخرة، ففي سورة الأعراف الحديث عن الحوار الذي يدور بين أهل الجنة

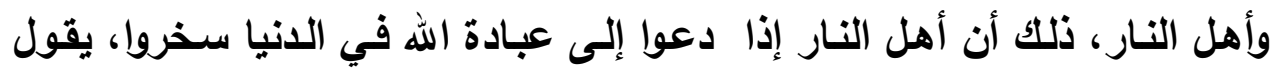

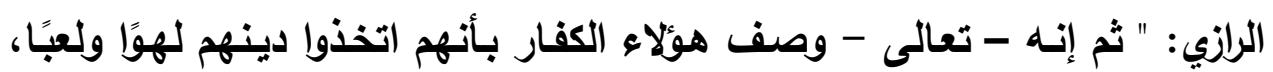
وفيه وجهان: الوجه الأول: أن الذين اعتقدوا فيه أنه دينهم تلاعبوا بـه ومـا كانوا

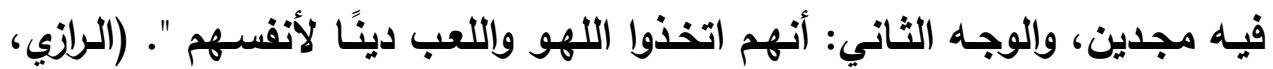

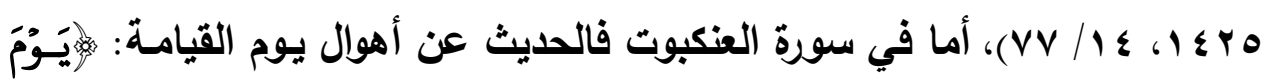

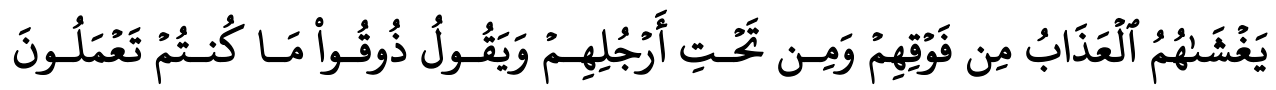

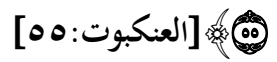
وذكر اسم الإثـارة ( ومـا هذه الحياة الدنيا ) زيادة في تحقير الدنيا في

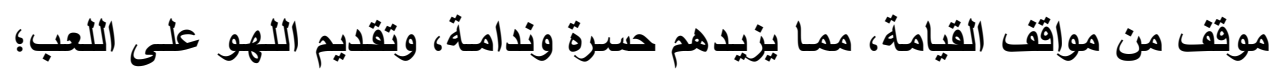
لأن اللهو فيه إثارة إلى انشغالهم عن هذا اليوم العظيم بأمور لا فائدة منها.

\section{المطاب الثـانسي: الحيساة غـرور}

جاء التحذير من الدنيا في كونها غرورًا، والغرور: " كل مـا يغرك من مـال وجاه وشهوة وشيطان، وقد فسّر بالثيطان، ويالانيا؛ لأنها تغر وتمر ، وأما الثيطان 
فإنه أقوى الغارين وأخبثهم " (الفيروزآبادي، د.ت، ع / 9 ؟ 1 ).

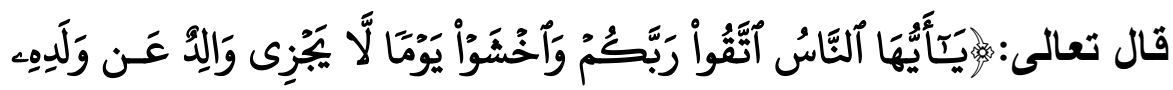

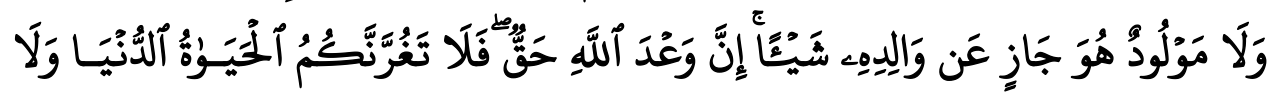

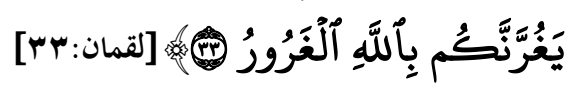

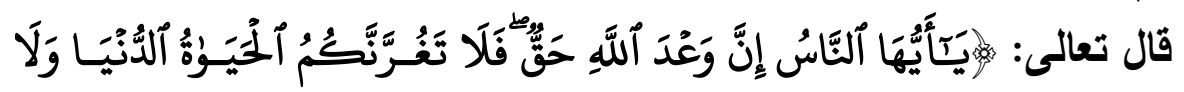

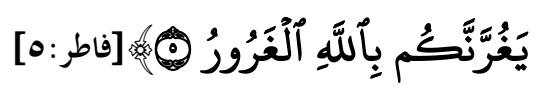

اتفقت الآيتان في الأسلوب الإنثـائي ( النداء )، والخطاب فيهما موجـها للناس، ويتأمل الآية في سورة لقمان يلحظ في التركيب: ( اتقوا ريكم واخشوا يومًا

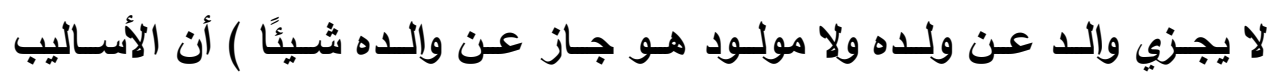

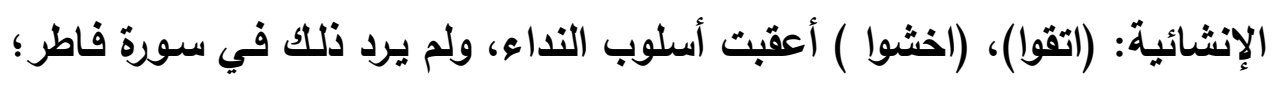

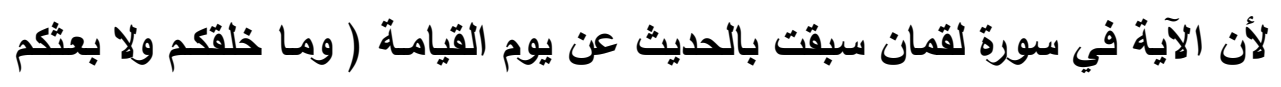

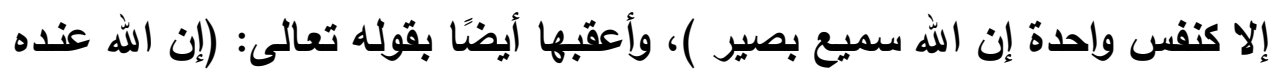

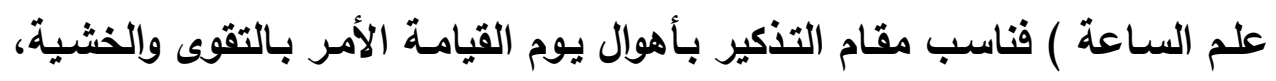

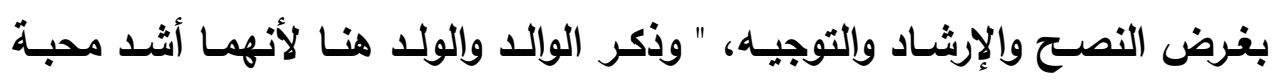

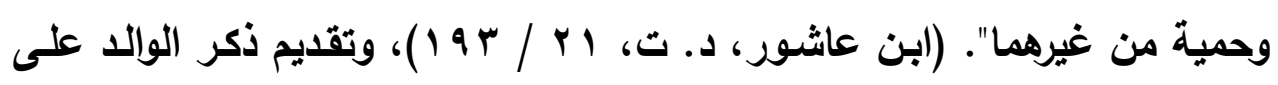
الولا؛ لأنه أثثد شفقة على ابنه.

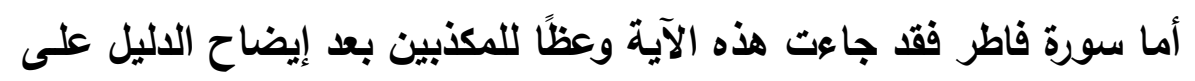

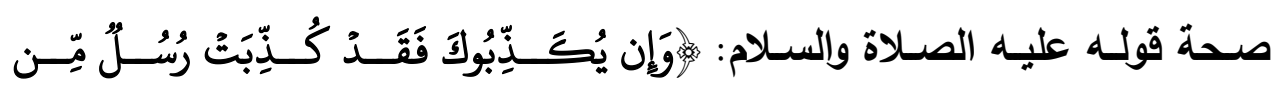

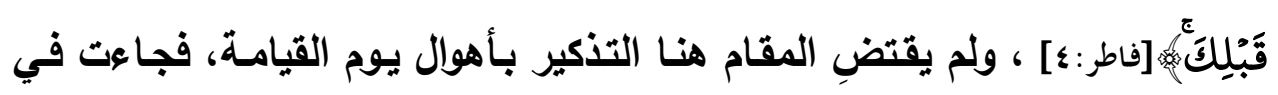

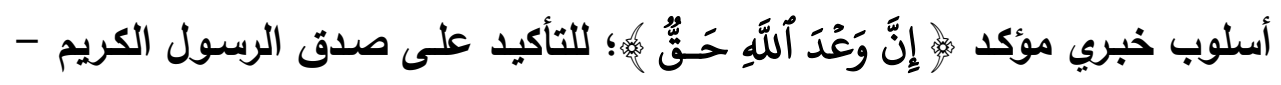
عليه أفضل الصلاة والتسليم- والله أعلم. 


\section{الفساتمسة}

الحمد الله رب العامين، أسبغ علينـا نعمهـ ظاهرة و باطنة، فأوجب علينـا شكره بجعلها مطية لعبادته، لا متعة في الدنيا وغرورًا. ويعد الانتهاء من هذا البحث في متثـابه النظم في التحذير من الدنيا وعدم الاغترار بها، والوقوف على روعة التعبير فيها وجمال التركيب المعجز، خرجت بيعض النتائج المتعلقة بهذا الموضوع، ومن أهمها ما يأتي:

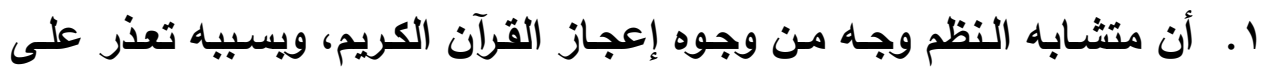
البشر الإتيان بمثله، فتصريف القول في موضوع واحد لا يقدر عليه إلا من

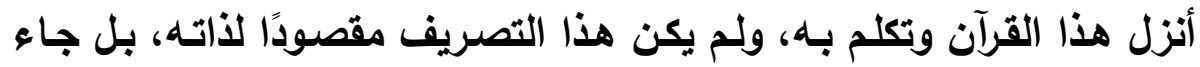
متوافقًا مع مقامه، ومع الغرض الذي سيق لله. r. أن ورود آيات كثيرة في التحذير من الدنيا والاغترار بها دلالة على أهمية

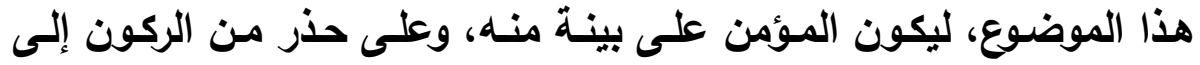

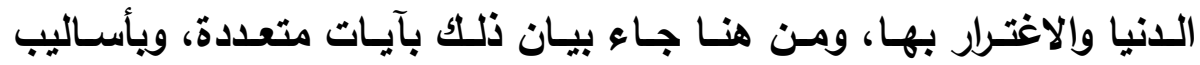
متنوعة، ومن هنا تتجلى أهمية هذا الموضوع. r. ارتباط تركيب الآيات المتثـابهة في التحذير من الدنيا وعدم الاغترار بها

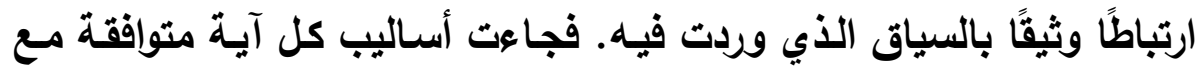
غرضها، محققة الغزض التي سيقت من أجله. ء. وفرة استخدام أسلوب القصر في الآيات المتثابهة في التحذير من الدنيا، وقد

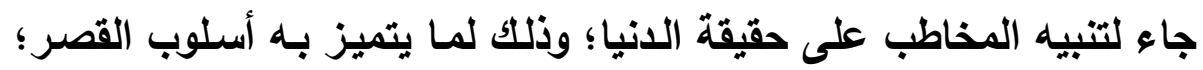
لاثتماله على النفي والإثبات، وذلك متوافق مـع طبيعة الحديث عن الاينا، وييان حقيقتها..

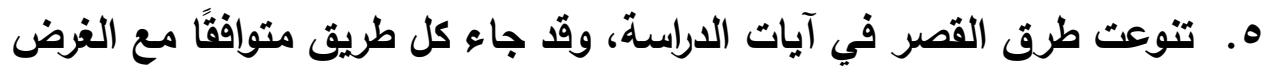

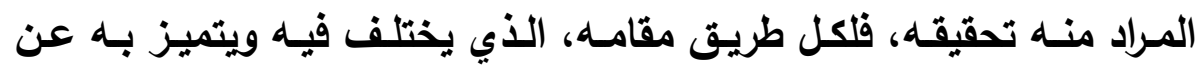


الطريق الآخر، ولذا كثر القصر بطريق النفي والاستثناء؛ لما يتميز بـه هذا الطريث في الالالة على القصر، وفي المقامات التي يأتي فيها، والحديث عن حقيقة الانيا والتحذير من الاغترار بها يستلزم هذا الطريق. 7. مراعـاة حـال المخاطـب فـي اسـتعمال طـرق القصـر ( إنمـا ) و( النفـي والاستثناء)، حيث استعملت (إنما) في سياق الحديث عن المخاطب غير المنكر، أما ( النفي والاستثناء ) استعملت مـع المخاطب الجاهل بالحكم، أو

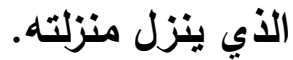

V. في تنوع الأساليب البلاغية في شواهد الاراسـة دلالـة على أن هذه الأسـاليب -على أهميتها- - لم تكن مقصودة لذاتها، بل كانت وسيلة لإظهار مقاصد القرآن الكبرى في مخاطبة الناس جميعًا باختلاف أحوالهم، وتعدد مقامـاتهم، فجاعت كل آية في مقامها اللائق بها، لتحقيق الغرض المرجو منها. وأدعو في خاتمـة البحث المختصسين بالدراسـات القرآنيـة إلى الالتفـات إلى موضوع متشابه النظم؛ لأهميته، خاصة فيما يتعلق بالجانب التطبيقي منـه، فهي الثمـرة الحقيقة لـورود الأسـاليب البلاغيـة المتعددة، التي تتـوع وتتعدد بـاختلاف المقامـات والغايـات، وثمـة كثير مـن الموضـوعات في القرآن الكريم بحاجـة إلى دراسـة متثـابه النظم فيهـا، كالحديث عن الظواهر الكونيـة: كالسـب والجبـال، وغيرهما، وكالحديث عن مواقف المؤمنين، وكذلك الكافرين، وسيظل القرآن معجزًا، ولن نحيط بوجوه إعجازه، ولكنها دعوة إلى التأمل والبحث الجاد. والحمد لله رب العالمين أولًا وأخرًا 


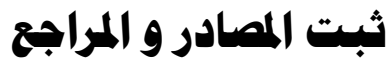

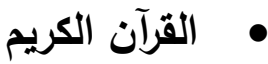

• ابـن عاشـور، محمـــ الطـاهر .( د. ت) التحريـر والتتـوير، د. ط، تـونس، دار سحنون للنشر والتوزيع.

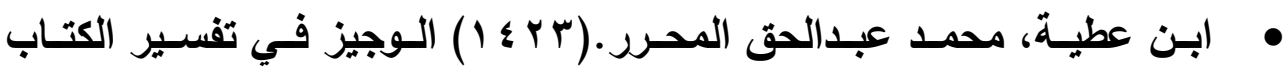
العزيز،، ط إ، بيروت، دار (بن حزم.

• ابن منظور ،محمد بن مكرم بن علي الأنصاري(9 (1 ) 1) لسان العرب، تحقيق:

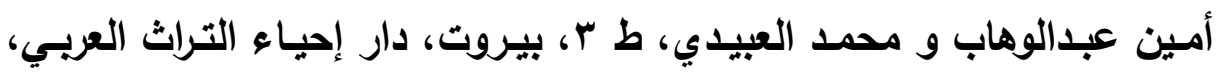
. 1 (1) 19

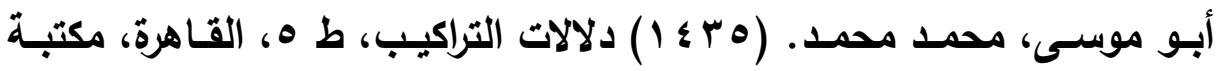

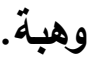

الإسكافي، أبو عبدالله محمد بن عبدالله.(r \& I ) درة التنزيل وغرة التأويل في

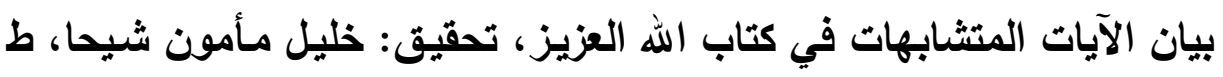

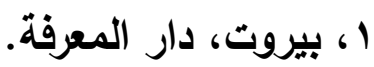

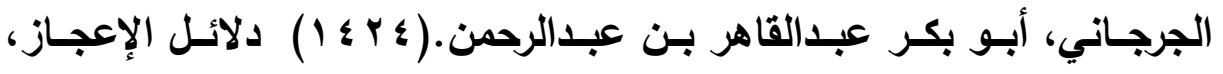
تحقيق: محمود شاكر ، طه، القاهرة، مكتبة الخانجي.

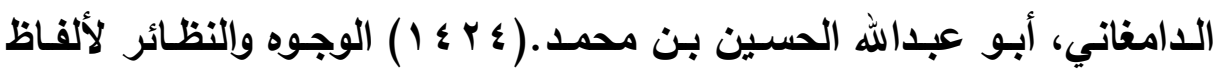

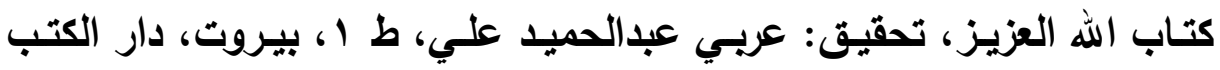

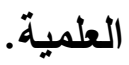

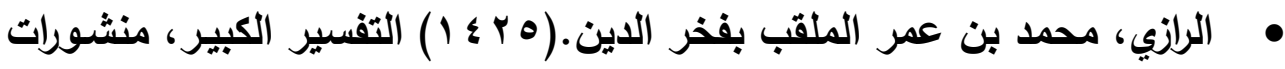
محمد علي بيضون، طץ، بيروت، دار الكتب العلمية. 


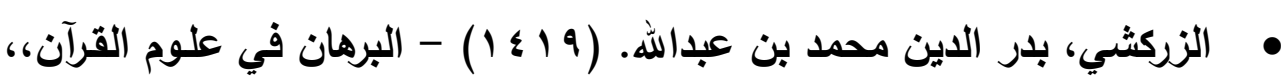
ت: محمد أبو الفضل إبراهيم، ط: rا، بيروت، المكتبة العصرية

السيوطي، أبو الفضل جلال الدين.(0 1 أ)، الإتقان في علوم القرآن، ط: ب،

$$
\text { بيروت، دار الكتب العلمية،... }
$$

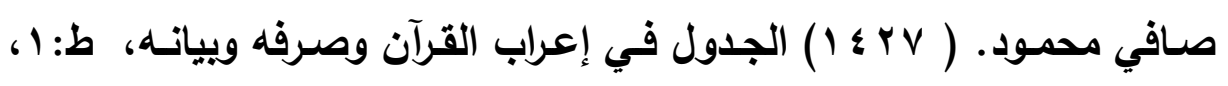
دمثق، دار الرشيد.

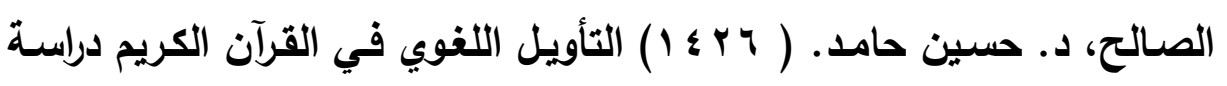
دلالية، ط: ا، بيروت، دار ابن حزم.

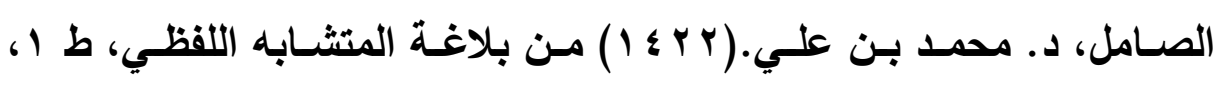

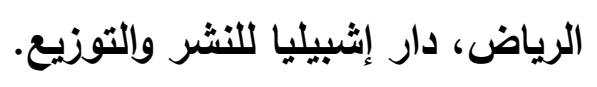

الطبري، أبـو جعفر محمد بـن جريـر .( • (1 أ) جـامع البيـان عن تأويـل آي

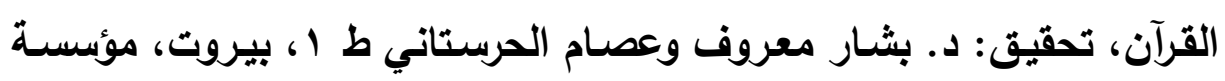
الرسالة.

العمادي، أبو السعود محمد.(ع اء 1) تفسير أبي السعود المسمى إرثاد العقل

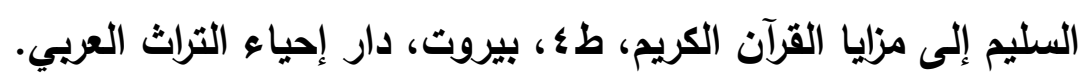

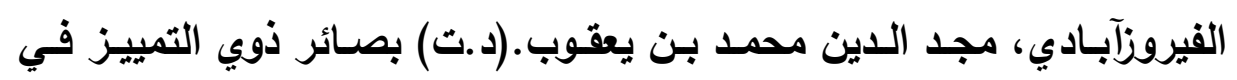
لطائف الكتاب العزيز، تحقيق محمد علي النجار د.ط ،بيروت، المكتبة العلمية.

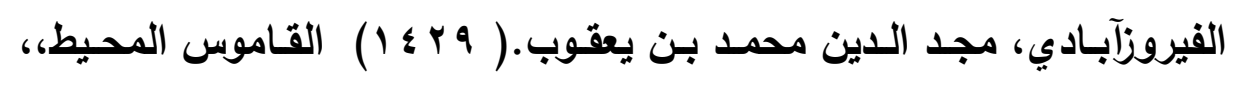
تحقيق: أنس الثافي وزكريا أحمد، د.ط، القاهرة، دار الحديث.

القرطبي، أبو عبدالله محمد بن أحمد.(0 ع \& 1) الجامع لأحكام القرآن، تحقيق: د. عبدالحميد هنداوي، طا، بيروت، المكتبة العصرية. 


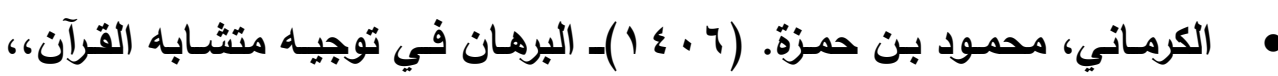
تحقيق: عبدالقادر أحمد عطا، طا، بيروت، دار الكتب العلمية.

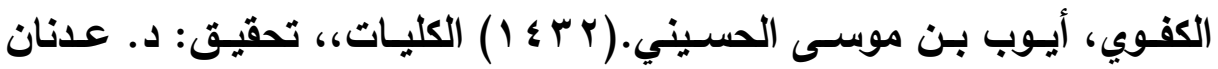
درويش و محمد المصري، ط r، دمشث، مؤسسة الرسالة.

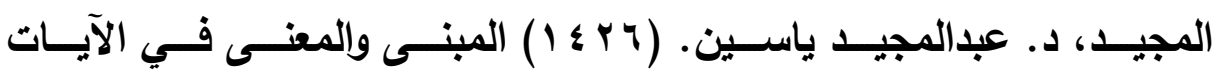

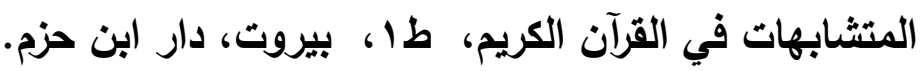

